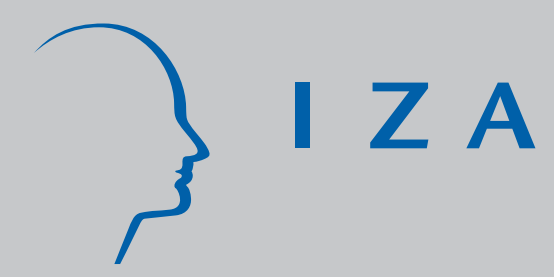

IZA DP No. 2205

Homo Reciprocans: Survey Evidence on Prevalence, Behavior and Success

Thomas Dohmen

Armin Falk

David Huffman

Uwe Sunde

J uly 2006 


\title{
Homo Reciprocans: Survey Evidence on Prevalence, Behavior and Success
}

\author{
Thomas Dohmen
}

IZA Bonn

\author{
Armin Falk \\ IZA Bonn and University of Bonn \\ David Huffman \\ IZA Bonn \\ Uwe Sunde \\ IZA Bonn and University of Bonn
}

Discussion Paper No. 2205

July 2006

IZA
P.O. Box 7240
53072 Bonn
Germany

Phone: +49-228-3894-0

Fax: +49-228-3894-180

Email: iza@iza.org

\begin{abstract}
Any opinions expressed here are those of the author(s) and not those of the institute. Research disseminated by IZA may include views on policy, but the institute itself takes no institutional policy positions.
\end{abstract}

The Institute for the Study of Labor (IZA) in Bonn is a local and virtual international research center and a place of communication between science, politics and business. IZA is an independent nonprofit company supported by Deutsche Post World Net. The center is associated with the University of Bonn and offers a stimulating research environment through its research networks, research support, and visitors and doctoral programs. IZA engages in (i) original and internationally competitive research in all fields of labor economics, (ii) development of policy concepts, and (iii) dissemination of research results and concepts to the interested public.

IZA Discussion Papers often represent preliminary work and are circulated to encourage discussion. Citation of such a paper should account for its provisional character. A revised version may be available directly from the author. 


\section{ABSTRACT \\ Homo Reciprocans: \\ Survey Evidence on Prevalence, Behavior and Success ${ }^{*}$}

Experimental evidence has convincingly shown the existence of reciprocal inclinations, i.e., a tendency for people to respond in-kind to hostile or kind actions. Little is known, however, about: (i) the prevalence of reciprocity in the population, (ii) individual determinants of reciprocity, (iii) the correlation between positive and negative inclinations within person, and (iv) consequences of reciprocal inclinations for wages, subjective well-being, friendships and other economic and social outcomes. Answering these questions requires moving out of the lab and using a large and representative subject pool, which combines information about subjects' reciprocal inclinations with extensive socioeconomic background information. In this paper we measure the reciprocal inclinations of 21,000 individuals. We show that most people state reciprocal inclinations, in particular in terms of positive reciprocity. However, there is substantial heterogeneity in the degree of reciprocity, and quite surprisingly, only a weak correlation between positive and negative reciprocity for an individual. In terms of determinants, being female, and increasing age, lead to greater positive and less negatively reciprocal tendencies. Taller people are more positively reciprocal, but height has no impact on negative reciprocity. The asymmetric impact of these determinants provides further indication that positive and negative reciprocity are fundamentally different traits, rather than the outcome of a single underlying tendency. In terms of economic implications, we provide the first evidence using a large representative survey that corroborates an important hypothesis arising from laboratory experiments: Positively reciprocal workers are in fact paid more, and exert greater effort, on the job. Moreover, positively reciprocal people are more likely to be employed, report having more close friends, and have a higher overall level of life satisfaction. In this sense, Homo Reciprocans - in the positive domain - is in fact more successful than his or her non-reciprocal fellows.

JEL Classification: D63, J3, J6

Keywords: reciprocity, trust, SOEP, wage regression, unemployment, happiness

Corresponding author:

Armin Falk

IZA

P.O. Box 7240

D-53072 Bonn

Germany

E-mail: falk@iza.org

\footnotetext{
* We thank the German Science Foundation (DFG) for financial support through SPP1169 (Potential for more Flexibility on Heterogeneous Labor Markets).
} 


\section{Introduction}

Reciprocity is an in-kind response to friendly or hostile acts. Numerous experiments have provided controlled evidence of this behavioral disposition. Positive reciprocity, the rewarding of cooperative or kind actions, has been documented in trust and gift-exchange games (see, e.g., Fehr, Kirchsteiger, Riedl 1993; Berg, Dickhaut and McCabe, 1995; Falk, 2006). Games that demonstrate the existences of negative reciprocity, the sanctioning of unkind or hostile actions, include, e.g., the ultimatum game (see, e.g., Güth, Schmittberger and Schwarze 1982, Camerer and Thaler 1995) or public goods games with punishment or sanctioning options (see, e.g., Fehr and Gächter 2000; Carpenter and Seki, 2005).

While experimental evidence has convincingly shown the existence of reciprocal inclinations, little is known about: (i) the prevalence of reciprocity in the population, (ii) individual determinants of reciprocity, (iii) the correlation between positive and negative inclinations within person, and (iv) consequences of reciprocal inclinations for wages, subjective well-being, friendships and other economic and social outcomes. Answering these questions is crucial for improving our understanding of the economic importance and implications of reciprocity. It requires moving out of the lab and using a large and representative subject pool, which combines information about subjects' reciprocal inclinations with extensive socioeconomic background information. This is what this study does.

Our evidence is based on a sample of roughly 21,000 individuals. The data are from the 2005 wave of the German Socioeconomic Panel (SOEP), which is representative of the adult population in Germany. For each individual, the data provide new survey measures of positive and negative reciprocity. The three questions concerning positive reciprocity ask about willingness to: (i) reciprocate a favor, (ii) exert effort to help somebody who was kind, and (iii) undergo personal costs in order to help someone who was helpful before. The three questions about negative reciprocity elicit willingness to: (i) take revenge for a serious wrong, (ii) retaliate for being put in a difficult position, and (iii) reciprocate an insult with an insult. All answers are given on a scale from 1 to 7 , where 1 means "does not apply to me at all" and 7 means "applies to me perfectly". While there have been various large surveys measuring willingness to trust - another important disposition affecting social interactions - we are not aware of any comparable data set that asks about reciprocal inclinations.

A key advantage of survey measures is that they can be administered to a large, representative sample. Paid experiments are typically restricted to much smaller samples 
due to budget constraints. The tradeoff is that survey questions are hypothetical, and thus do not give respondents a financial incentive to accurately report their true behavioral inclinations (for a discussion, see Camerer and Hogarth, 1999). However, we discuss previous evidence showing that survey questions about trust can be used to predict actual trusting behavior. We also compare our findings on determinants of reciprocity, discussed below, to the determinants of reciprocal behavior observed in paid field experiments. We find converging evidence, providing an additional indication that our measures do in fact capture an individuals' reciprocal inclinations in a behaviorally relevant way.

We begin our analysis by exploring how reciprocity is distributed in the population. As emphasized, e.g., by Falk and Fischbacher (2006), the prevalence of reciprocal types in the population is one crucial factor determining whether reciprocal or selfish play is predicted to dominate in the final market equilibrium. ${ }^{1}$ In our data it turns out that the large majority of respondents agree with the above-mentioned statements, implying that reciprocal inclinations are the rule rather than the exception. A closer inspection, however, reveals that there is substantial individual heterogeneity in the strength of reciprocal inclinations. There are also substantial differences between positive and negative reciprocity: Not only are there more positively reciprocal respondents than negatively reciprocal ones, but the correlation between a respondent's positively and negatively reciprocal inclinations is surprisingly low. These latter findings point to an important complication. Positive and negative reciprocity might be expected to derive from the same underlying trait, a general tendency to respond in kind. Instead, our findings suggest that these traits are behaviorally distinct, with potentially different determinants. Thus it may be more accurate to speak of multiple types, such that individuals may be positively reciprocal, negatively reciprocal, or both.

In a next step we analyze individual determinants of reciprocity in detail, and find a number of interesting results. The first finding is a gender difference: While women tend to be significantly more positively reciprocal, men are significantly more negatively reciprocal. The latter finding is consistent with findings on the relation between testosterone levels and negative reciprocity in ultimatum bargaining (Burnham, 1999). There is also an age effect which, like gender, is different with respect to positive and negative reciprocity. Older people are significantly more willing to reward kind behavior than younger people, but they are significantly less likely to punish unkind behavior. Finally, an inclination to

\footnotetext{
${ }^{1}$ Another crucial factor is the particular set market institutions that are in place. Depending on institutions it may take only a few selfish types to pull the market towards an equilibrium characterized by universally selfish behavior, or alternatively, reciprocal types may be able to discipline selfish types and enforce cooperative behavior.
} 
be positively reciprocal is increasing in the height of an individual. There is no height effect for negative reciprocity. The asymmetric findings regarding the determinants of positive and negative reciprocity reinforce the impression that these are fundamentally different behavioral dispositions.

We are also interested in assessing the economic and social consequences of reciprocal inclinations. A particularly important economic implication of reciprocity concerns labor relations. Numerous studies, both theoretical and empirical, have argued that reciprocally motivated agents respond to fair treatments such as higher wages with higher levels of motivation and work effort (see, e.g., Akerlof, 1982; Bewley, 1999; Fehr and Falk, 1999; Fehr, Kirchsteiger and Riedl, 1993). To the best of our knowledge this paper is the first to test this claim on the basis of a large survey. We measure work effort using total hours worked, overtime hours worked and data on absenteeism. Strikingly, the results based on hours worked are strongly consistent with the fair-wage effort hypothesis: We find a significantly positive correlation between the degree of positive reciprocity and effort on the job. The impact of reciprocity is comparable in size to that of other important variables: One additional point on the positive reciprocity scale has the same effect on hours worked as an additional year of experience, or half a year of additional education. Turning to absenteeism, the interesting finding is that positive reciprocity has no impact, but negatively reciprocal types are significantly more likely to take sick days. A final result concerns another key labor market variable, unemployment. We discuss arguments based on laboratory evidence, and theories of social preferences, which suggest that individuals who are positively reciprocal may be better able to maintain long-term employment relationships, whereas negatively reciprocal individuals may be more likely to be unemployed. We find evidence supporting this hypothesis: The unemployed are in fact significantly less positively reciprocal, and significantly more negatively reciprocal. In terms of magnitude, one additional point on the reciprocity scale has about the same impact on the probability of being employed as half a year of education.

We conclude the results section by checking whether Homo Reciprocans is more successful than his non-reciprocal fellows. ${ }^{2}$ Since reciprocal individuals are willing to reward and sanction fair or unfair behavior even if this is costly, one might speculate that Homo Reciprocans has a strategic disadvantage, because of resources "wasted" on rewards and sanctions. On the other hand we know from evolutionary game theory that if types can

2 This investigation is in line with a growing literature that focuses on the importance of personality, attitudes, or non-cognitive skills for determining the economic success of individuals also in an evolutionary context (see Bowles and Gintis, 2002; Heckman and Rubinstein, 2001; Heckman et al., 2006; Osborne, 2005). 
be signaled it can be an advantage to credibly signal that one is willing to punish unfair behavior or to reward fair treatments. For example, firms that expect reciprocal actions by their workers may have a reason to pay higher wages or to treat workers with respect (Akerlof, 1982; Bewley, 1999). Likewise, groups consisting of a sufficient number of reciprocators will find it easier to enforce the voluntary provision of public goods, which may result in higher efficiency (Fehr and Gächter 2000). We test the success of Homo Reciprocans using three different measures: Number of close friends, income, and subjective well-being.

The SOEP provides answers to the question how many close friends respondents have. Since friendships are pleasurable per se but are also an important part of a person's network, having more friends is a possible indicator for a variety of positive social and economic outcomes. In our analysis we regress the number of close friends on being positively or negatively reciprocal and find a strong and asymmetric effect: While positive reciprocity seems to promote friendship networks, negative reciprocity is harmful. Both effects remain significant after controlling for a large set of variables.

Turning to a financial measure of success, we regress monthly labor income on both positive and negative reciprocity, and find that monthly labor income is significantly higher for people who are positively reciprocal. The effect is highly significant, controlling for the variables typically included in a Mincerian wage regression: Experience, years of education, gender, and occupation. In terms of magnitude, income is about 14 percent higher for those who answer "applies to me perfectly" on the 7-point scale compared to those who state "does not apply to me at all" (assuming a linear effect over the whole range of answer categories). However, higher incomes for positively reciprocal people are apparently explained by the fact that these people work harder. Once we control for hours worked, the positive reciprocity coefficient gets considerably smaller and insignificant. Note that this finding is consistent with the fair wage-effort relation: Reciprocal workers respond in kind by working longer for receiving higher wages.

Our final success measure is subjective well being, or happiness. Although the precise meaning of happiness is somewhat elusive, many social scientist agree that happiness is an important goal of human life and perhaps best summarizes success and achievement in a general way (Frey and Stutzer, 2002). It is therefore quite natural to ask whether reciprocal agents are happier or less happy than non-reciprocal types. Our results are striking and once again reveal an asymmetry between positive and negative reciprocity: While happiness is positively correlated with positive reciprocity the opposite holds for negative reciprocity. Both effects are sizeable, robust and significant. 
In sum our results show that most people state reciprocal inclinations, in particular in terms of positive reciprocity. Heterogeneity in the degree of reciprocity prevails, and quite surprisingly the correlation between positive and negative reciprocity is only weak. This latter finding suggests that positive and negative reciprocity are distinctive behavioral concepts. This conjecture is corroborated by the fact that important determinants of reciprocity, such as gender, age and height are systematically different for positive and negative reciprocity. In terms of economic implications we find quite convincing support for previous laboratory findings that highlight a link between fair treatment, positive reciprocity, and work effort. Moreover, positively reciprocal people report having more close friends, and a higher overall level of life satisfaction. In this sense, Homo Reciprocans - in the positive domain - is in fact more successful than his or her non-reciprocal fellows.

The rest of the paper is organized as follows. In the next section we describe the data and our reciprocity measures, and discuss evidence on the behavioral validity of survey measures. Section 3 presents results on the prevalence of reciprocity in the population and determinants of individual differences. Section 4 explores consequences of reciprocity, including behavior in employment relationships, and successful outcomes in life, measured by income, friendships, and life satisfaction. Section 5 concludes.

\section{Data}

Our data come from the German Socio-Economic Panel (SOEP). The SOEP is a representative panel survey of the resident population of Germany (for a detailed description, see Wagner et al., 1993, and Schupp and Wagner, 2002). The initial wave of the survey was conducted in $1984 .{ }^{3}$ The SOEP surveys the head of each household in the sample, but also gives the full survey to all other household members over the age of 17 . Respondents are asked for a wide range of personal and household information, and for their attitudes on assorted topics, including political and social issues. The survey also includes various subjective measures (e.g., life satisfaction) which are widely used and recognized for their quality (see, e.g., Ferrer-i-Carbonell and Frijters, 2004; Frijters et al., 2004a and 2004b; van Praag and Ferrer-i-Carbonell, 2004).

In this study we rely mainly on data from the 2005 wave of the survey, which includes 21,105 individuals from 11,453 households. In this wave, six different measures of reciprocity were included in the SOEP for the first time. Respondents were asked to indicate

3 The panel was extended to include East Germany in 1990, after reunification. For more details on the SOEP, see www.diw.de/gsoep/. 
on a 7-point scale how well each of the following six statements (translated from German) applies to them personally: ${ }^{4}$ (1) If someone does me a favor, I am prepared to return it; (2) If I suffer a serious wrong, I will take revenge as soon as possible, no matter what the cost; (3) If somebody puts me in a difficult position, I will do the same to him/her; (4) I go out of my way to help somebody who has been kind to me before; (5) If somebody insults me, I will insult him/her back; (6) I am ready to undergo personal costs to help somebody who helped me before. An answer of 1 on the scale means: "does not apply to me at all" and choosing 7 means: "applies to me perfectly". Importantly, questions (1), (4) and (6) ask about positive reciprocity, while questions (2), (3) and (5) ask about negative reciprocity. Also, two of the questions ask explicitly whether the respondent would incur costs in order to be negatively reciprocal (question 2) or positively reciprocal (question 6). In total, 20,774 individuals responded to all six reciprocity measures. ${ }^{5}$

An important concern when using survey questions to measure preferences or attitudes is that the measures are not incentive compatible. As a result, various factors such as selfserving biases, strategic motives, or lack of attention could potentially lead respondents to distort or miss-report their true tendency to exhibit reciprocal behavior. Previous research has shown, however, that survey questions asking about another important aspect of social preferences - willingness to trust - can reliably predict actual trusting behavior. A particularly relevant example is Fehr et al. (2003), who uses the same subject pool and sampling design as our survey. They conduct a field experiment with a representative sample of 429 German adults, in which individuals answer attitudinal questions about willingness to trust, and participate in modified trust game involving real monetary stakes. Fehr et al. find that the survey questions asking about trust reliably predict trusting behavior in the experiment. Other studies have conducted trust games with large representative samples, in different countries, and have shown that similar trust questions are also behaviorally valid (see Bellemare and Kröger (2005) for the Netherlands and Falk and Zehnder (2006) for the citizens of Zurich in Switzerland).

It would be ideal to include the reciprocity measures used in this study in a large scale field experiment, and test whether they reliably predict reciprocal behavior. Although this experimental exercise is beyond the scope of the current paper, a first step towards such a validation exercise is to look at the characteristics that determine reciprocal behavior in the experiment by Fehr et al., and see whether these characteristics have a similar impact

\footnotetext{
${ }^{4}$ German versions of all six questions are available online, at the following web site: www.diw.de/deutsch/sop/service/fragen/fr2005/personen_2005.pdf.

5 The response rate is very high, and quite similar, across the individual questions. For each question, we observe responses from at least 99 percent of the 21,105 individuals in the sample.
} 
on reciprocity as measured by the survey questions in our study. For example, if age reliably predicts more positively reciprocal behavior by the second mover in their trust game, it would be reassuring to find that age has a similar effect on the survey measures of positive reciprocity used in our study. In fact, we do find converging evidence on the determinants of reciprocity, providing another indication that the survey measures are likely to be behaviorally valid. We discuss these findings in detail when we present our results on the determinants of reciprocity.

\section{Prevalence and Determinants of Reciprocity}

\subsection{Prevalence}

Evidence from laboratory experiments suggests that individuals differ in their willingness to behave reciprocally. For example, Fehr and Gächter (2000) survey evidence from a variety of different types of experiments on social preferences, which look at both positive and negative reciprocity. They note that a substantial proportion of subjects in these experiments behave reciprocally, but that there is also a non-trivial fraction of individuals who behave completely selfishly. It is an important open question to what extent reciprocity is pervasive outside of the laboratory, in the general population. Experiments typically use only college students as subjects, and some subjects who do not appear reciprocal in the lab might in fact behave reciprocally in less artificial circumstances, or given different parameter values for the decision problem. We begin our analysis with an exploration of the pervasiveness of reciprocity in the general population, distinguishing between positive and negative reciprocity.

Figure 1 shows the distributions of answers to each of the six different reciprocity measures. A first observation is that most people indicate some degree of positive reciprocity. For each of the three positive reciprocity statements, less than 5 percent say that the statement does not apply to them at all. The modal response is a 6 or 7 for all three statements, indicating that a substantial number of people report that the statement applies to them almost perfectly. A fraction ranging from about 15 to 40 percent state some other, intermediate level of agreement, depending on the measure. For negative reciprocity, the modal response is 1 or 2 , corresponding to zero or only mild negatively reciprocal inclinations. However, compared to positive reciprocity, there is greater variance within each measure. For each of the questions, a substantial number of individuals, roughly 50 percent, report an intermediate level of agreement that they are negatively reciprocal, from 3 to 5 . There is also a non-trivial fraction, roughly 10 percent for each question, who choose a 6 or 7 , 
indicating almost complete agreement with even the strongest statements about negative reciprocity.

It is noteworthy that agreement with positive reciprocity statements appears to be decreasing in the level of cost mentioned in the question. This is consistent with economic theory, which assumes that people respond to incentives, and with evidence from laboratory experiments, which shows that willingness to reciprocate decreases in the costs of doing so. For example, the top panel for positive reciprocity shows that more than 60 percent fully agree that they are willing to return a favor, but this drops to around 35 percent in the middle panel, where the statement mentions having to go out of one's way, and to only 22 percent in the bottom panel, for the statement that explicitly mentions having to undergo personal costs. For negative reciprocity, there is less evidence that willingness to reciprocate depends on costs; the distribution is quite similar across the three different statements. This could indicate that people are less sensitive to costs when it comes to punishing. Another explanation is that the different statements involve changes in the benefits of punishment, which offset increasing costs. For example, the statement that involves taking revenge at any cost also states that this is in response to a serious wrong. The statement about reciprocating an insult does not mention a cost, but redressing an insult may be less important than responding to a serious wrong, potentially explaining why willingness to reciprocate is similar in these two situations.

In order to get a sense of individuals' overall tendency to be positively or negatively reciprocal, we average responses over the three positive and negative statements, respectively. Figure 2 shows the distributions of these averages. Note that the bins do not correspond to integer values because they are constructed using averages of different values on the response scales. Means and standard deviations for positive and negative reciprocity are $5.88(0.91)$ and 3.11 (1.46), respectively. The qualitative message is unchanged by collapsing the individual measures of positive and negative reciprocity in this way. Most people report substantial inclination to be positively reciprocal. For negative reciprocity there is more variation, such that many people report only weak agreement with negative reciprocity statements on average, but a non-trivial fraction report almost complete agreement. In our analysis later on, we will focus on these overall measures of positive and negative reciprocity for each individual.

An interesting question is the extent to which positive and negative reciprocity are correlated for an individual. One possibility is that an individual who retaliates strongly against hostile or unkind actions is also likely to exhibit a similarly strong inclination to reward kind actions when they arise. In this case one would expect to find that agree- 
ment with statements about positive and negative reciprocity are positively correlated. Alternatively, it could be that these two types of behaviors are unrelated, or even negatively correlated. There is some basis for thinking that positive and negative reciprocity might have different roots. For example, positive reciprocity tends to be weaker than negative reciprocity in laboratory experiments (see Abbink et al., 2000; Falk and Fischbacher, 2006). This asymmetry suggests that these behaviors may be different in some way. In our data we find some evidence to support this latter hypothesis: The correlation between positive and negative reciprocity for an individual is only 0.024 , suggesting that these are different traits. Although speculative, one possibility is that negative and positive reciprocity are different because they tap into different emotional responses. For instance anger appears to be important for explaining punishment behavior in experiments (Fehr and Gächter, 2002). There is less evidence on the specific emotions involved in positive reciprocity, but candidates include gratitude, or possibly anticipated guilt associated with not rewarding.

\subsection{Determinants}

Given that we observe substantial heterogeneity in the degree of reciprocity across individuals, we next turn to an investigation of potential determinants of these individual differences. For each individual, we construct measures of overall positive and negative reciprocity, as above, by taking the arithmetic average of responses to the three positive and three negative statements. ${ }^{6}$ We then investigate the impact on reciprocity of various personal characteristics that are plausibly exogenous to the individual, namely, gender, age and height. Because these characteristics are exogenous, it is possible to make causal statements about the coefficients we report in our regression analysis. As a second step, we add controls for many other personal characteristics, which are less clearly exogenous, and investigate the robustness of our results.

Table 1 presents results on the determinants of reciprocity. In columns (1) and (2) the dependent variable is the average measure of an individual's positive reciprocity, and in columns (3) and (4) the dependent variable is the corresponding measure for negative reciprocity. Coefficients are estimates from OLS regressions. Standard errors shown in brackets are robust, and corrected for potential correlation of the error term (clustering) across members of the same household. Columns (2) and (4) contain the results for

\footnotetext{
${ }^{6}$ An alternative approach is to use the two main principle components obtained from the six reciprocity measures, which correspond to positive and negative reciprocity. We find that the qualitative results obtained using this approach are almost identical to those obtained for the average measures.
} 
specifications that include additional controls such as parental education, marital status, occupation, nationality, and educational attainment. For the sake of brevity we do not report the coefficients for these controls in the table. The full specification, with all coefficients, is shown in Table A.1 in the Appendix.

A first interesting finding is a gender difference. Column (1) shows that women are significantly more positively reciprocal than men, controlling for other exogenous determinants. The effect is still marginally significant when we add the full set of additional controls in column (2). In the case of negative reciprocity there is also a gender difference, which remains highly significant and robust even after adding all controls. As shown in columns (3) and (4), women are also significantly less negatively reciprocal than men. These findings have potentially important implications for understanding differences in male and female behavior. They are also interesting in light of evidence from Burnham (1999), showing that there is a link between testosterone levels and negative reciprocity, where negative reciprocity is measured by the probability that an individual rejects an unfair offer in the ultimatum game. ${ }^{7}$ Notably, the fact that gender affects negative and positive reciprocity in different ways provides further evidence that these are distinct traits, with different determinants. Various other variables, discussed below, also have such asymmetric affects on the different types of reciprocity.

A second finding is that age has an impact on reciprocity. As age increases, individuals become more positively reciprocal. At the same time, increasing age leads individuals to become less negatively reciprocal. In previous research, we have found that age affects another fundamental type of preferences, namely attitudes towards risk taking, such that older people become less willing to take risks (Dohmen et al., 2005). The age effect for reciprocity could reflect accumulating experiences, or social prescriptions regarding age-appropriate behavior, or possibly even biological changes occurring as the body ages (one might speculate that changing testosterone levels could play a role in explaining the age effect). A third finding is that height also has an impact. Taller individuals are significantly more willing to behave in a positively reciprocal way. Interestingly, height has no impact on negative reciprocity. Height has been linked to success in life, in the form of higher wages (Persico et al., 2004). Our analysis in the next section sheds light on whether positive reciprocity could be one channel for such a height effect, because we explore how positive reciprocity affects different measures of success, including income and life satisfaction.

\footnotetext{
${ }^{7}$ Most experimental evidence has focused on gender differences in positive reciprocity. This evidence is based mainly on college student subjects, and is mixed, with some finding no difference and others finding that women are more positively reciprocal (see Croson and Gneezy, 2004).
} 
In Table A.1 in the Appendix there are a number of other noteworthy correlations between reciprocity and various control variables. For example, married individuals are more positively reciprocal, but are not different from the unmarried in terms of negative reciprocity. Individuals with good subjective health status are more positively reciprocal and less negatively reciprocal. Another interesting finding concerns the fact that university students are less positively and less negatively reciprocal than other members of the population. The importance of this finding stems from the fact that university students are the typical subjects in laboratory experiments. These experiments have often been criticized in terms of exaggerating the importance of social preferences because of a potential subject pool bias and self selection of experimental subjects. Our findings suggest that, if anything, laboratory experiments have underestimated the importance of social preferences.

Our findings on the determinants of reciprocity are similar to the determinants observed by Fehr et al. (2003), who measure reciprocal behavior in an incentive compatible way, for a similar albeit much smaller group of subjects. ${ }^{8}$ Fehr et al. also find that increasing age, and being married, are associated with more positively reciprocal behavior by second-movers in the trust game. One notable difference is that they find no gender difference for positive reciprocity, whereas we find a significant difference. In their sample of the Dutch population, Bellemare and Kröger find a similar gender difference to ours. Falk and Zehnder (2006), on the other hand, do not find a gender difference among residents of Zurich. They do find, however, the same positive effect of being married. Interestingly, Fehr et al. also find a difference according to employment status: The unemployed are less positively reciprocal than employed individuals. In the next section we report a similar finding. This converging evidence is reassuring, providing an initial indication that the measures of reciprocity included in our survey can in fact be interpreted as capturing differences in reciprocal behavior.

\section{Behavioral Correlates of Reciprocity}

In this section, we investigate which types of behavior are associated with positive and negative reciprocity. Guided by the experimental literature, in which studies have often investigated how reciprocity affects the employment relationship, we first investigate the

\footnotetext{
8 The only large experiment with a non-student subject pool on negative reciprocity, which we are aware of, is Gächter and Herrmann (2006) who study a public goods experiment with punishment conducted with 566 urban and rural participants in Russia. They basically find no significant socio-demographic determinants of punishment, i.e., negative reciprocity.
} 
correlations between reciprocity and key labor market variables, such as work effort, and employment status. We then turn to another important open question: How successful in life is Homo Reciprocans? We measure success in a variety of ways, including number of close friends, income, and life satisfaction.

\subsection{Reciprocity and the Employment Relationship}

One strand of the experimental literature has documented a willingness of workers to exert high effort levels, even in settings where effort is not enforceable and a purely selfish worker would shirk. The leading explanation for such behavior is that workers are positively reciprocal, and that firms can elicit high effort levels by paying generous wages. In fact, firms are observed to pay greater than market clearing wages in these experiments, and average worker effort levels respond to the level of the wage offered in a way consistent with reciprocity (see Fehr, Kirchsteiger, and Riedl, 1993; Fehr and Falk, 1999; Gneezy, 2003). Thus, positive reciprocity can potentially explain why it may be profitable for firms to pay efficiency wages. With our measures of reciprocity we provide direct evidence from the field on whether positive reciprocity is associated with higher effort levels in the workplace. We use the number of hours worked, and number of overtime hours, as measures of work effort, and also another measure frequently used in the literature, an individual's frequency of absenteeism.

Column (1) of Table 2 presents results from an hours regression, where the dependent variable is the self-reported average number of weekly hours (including overtime). Coefficients are OLS estimates, with robust standard errors in brackets, adjusted for clustering on household. Independent variables include an individual's degree of positive and negative reciprocity, and standard controls such as log gross labor income, years of schooling, experience, experience squared, gender, occupation, and employment status. ${ }^{9}$ The striking finding is that there is a significant positive correlation between the degree of positive reciprocity and the number of hours worked, consistent with behavior observed in experimental labor markets. In terms of magnitude, one additional point on the reciprocity scale has about the same impact as an additional year of experience, or half a year of education. Negative reciprocity, on the other hand, is unrelated to hours worked. In Column (2) of Table 2 the dependent variable is equal to 1 if an individual reported working some overtime during the past month and zero otherwise. Coefficient estimates are marginal effects from a Probit regression. Controls are the same as in the first column.

\footnotetext{
9 The experience variable corresponds to the usual concept of potential experience, computed as age minus years of schooling minus 6 .
} 
Here we see that positive reciprocity is associated with a significantly higher probability of working overtime hours. Interestingly, negative reciprocity is associated with a lower probability of working overtime. Column (3) shows the impact of reciprocity on the selfreported number of overtime hours worked during the last month, converted into average weekly overtime hours. Here we see that positive reciprocity is associated with more overtime hours, controlling for income. The coefficient is almost the same size as for hours regression in column (1), suggesting that most of the effect of positive reciprocity on hours comes through additional overtime rather than longer contractual work weeks. In addition Column (3) shows that negative reciprocity adversely affects the probability of working overtime.

Columns (4) and (5) of Table 2 presents results using absenteeism as a measure of effort. The dependent variable is the number of days an individual has been absent during the previous year. ${ }^{10}$ The sample excludes those who had a long-term illness, defined as an illness lasting longer than six weeks. In order to account for a substantial number of observations with zero days absent, coefficients are estimated using a Tobit regression. Independent variables include an individual's degree of positive and negative reciprocity, as well as age, gender, height, subjective health status, and additional controls. The table shows that positive reciprocity has no significant impact on absenteeism. Negatively reciprocal inclinations, however, are associated with taking significantly more sick days. Of course some caution is warranted in interpreting data on absenteeism. However, if one interprets at least part of the observed absenteeism as shirking or some kind of sanctioning, the observed relation with negatively reciprocal inclinations clearly makes sense. Overall, our findings on work effort support the hypothesis that effort levels in the workplace are increasing in positive reciprocity. There is also evidence that workers' negatively reciprocal inclinations find expression through reduced willingness to work overtime, and greater absenteeism.

A third labor market result concerns unemployment. Based on experimental and field evidence, there is reason to think that positive reciprocity may help sustain successful employment relationships, and that negative reciprocity may be associated with relationship dissolution, and unemployment. For example, Brown, Falk, and Fehr (2004) conduct an experiment where long-term relationships can emerge endogenously between a firm and a worker, and find that positive reciprocity is important for establishing successful long-

${ }^{10}$ Information on absenteeism was collected in the 2004 wave and the 2003 wave. In each year, the question referred to numbers of days absent in the previous year: 2002 and 2003, respectively. Only those individuals who were also in SOEP sample in 2004 or 2003 are included in the analysis for the corresponding regression. 
term relationships. In the experiment, effort is not enforceable, so short-run self-interest dictates that workers shirk and firms pay minimal wages. Relationships that ultimately last a long time, however, start with high wages, and higher effort levels than shorter relationships. Workers earn more in long-term relationships than in short-term relationships, but also work harder, because they reciprocate the generous wages. To the extent that positive reciprocity also helps sustain successful employment relationships outside of the lab, one would then expect that positively reciprocal individuals are less likely to be unemployed.

On the other hand, there is reason to believe that negatively reciprocal types may be more likely to be unemployed. Experiments show that people are willing to punish those who treat them unfairly, even if this is personally costly (see Fehr and Gächter, 2002; Quervaine et al., 2004). For this reason, negatively reciprocal types might be more likely to quit their job following unfair treatment by an employer than positively reciprocal types. Alternatively, negatively reciprocal types might decide to punish the employer by shirking on the job (see also our findings on absenteeism, discussed above). In this case, the employer has an incentive to preempt such retaliation by dismissing the worker. One dramatic example of the damage caused by disgruntled workers is provided by Krueger and Mas (2004), who provide strong evidence that the dangerous increase in defective automobile tires produced by Bridgestone/Firestone occurred precisely during the most contentious period of a long labor strike. ${ }^{11}$

In order to test these hypotheses regarding the relationship between unemployment and reciprocity, Table 3 presents regressions where the dependent variable is an indicator for employment status, equal to 1 if an individual is currently registered as unemployed, and zero otherwise. Controls include years of education, gender, age, region of residence, and an indicator for German citizenship. The table shows that the unemployed are in fact significantly less positively reciprocal than the employed. On the other hand, they are significantly more negatively reciprocal. These findings are consistent with the hypothesis that individuals' reciprocal inclinations affect their labor market experience, in terms of ability or willingness to sustain long-term employment relationships. Again, in terms of magnitude reciprocity is as important as other key economic variables. One additional point on the reciprocity scale has the same impact on the probability of being employed as half a year of additional schooling.

${ }^{11}$ Related evidence shows that managers of firms are reluctant to cut nominal wages, for fear that this will trigger negative reciprocity and retaliation from workers (see Bewley, 1999). An implication is to dismiss workers instead of cutting wages and it is quite plausible that dismissing negatively reciprocal workers seems optimal. 


\subsection{How Successful is Homo Reciprocans?}

As discussed in the introduction, there are various reasons why reciprocal behavior could lead to better or worse outcomes for an individual. On the one hand, reciprocity is costly, because individuals spend resources to reciprocate favors or insults, in circumstances where material self-interest would dictate no response. On the other hand there are potential long-term benefits, for example, heightened ability to sustain relationships, or ability to credibly threaten punishment of unfair behavior, that could outweigh these costs. It is therefore interesting to investigate empirically how Homo Reciprocans fares in life, compared to individuals who are only weakly reciprocal or not reciprocal at all. This is also important from an evolutionary game theoretic perspective that is concerned with explaining why different types (such as selfish or reciprocal) can coexist (Bowles and Gintis, 2004).

We use three types of outcomes as measures of success. The first is the number of close friends. This is interesting both because it is a sign of well-being, and because it indicates a type of social intelligence, or ability to sustain long-term relationships. The second is income, and the third is subjective well-being or life satisfaction.

Friendship is known to be associated with various types of positive outcomes for an individual, including greater life satisfaction and better health. Social networks have also been linked to success in finding employment and receiving informal credit. To the extent that reciprocity sustains or damages friendships, therefore, it has the potential to affect individual well-being. Column (1) of Table 4 presents regressions where the dependent variable is the number of "close friends" that an individual reports having. ${ }^{12}$ Independent variables in column (1) include the degree of positive and negative reciprocity for the individual, and the usual exogenous factors as well as additional controls. The coefficient estimates show that reciprocity does have a strong effect on friendship relations. Positive reciprocity is associated with a greater number of close friends, and negatively reciprocal individuals have significantly fewer close friends. In terms of friendship, then, increasing positive reciprocity appears to be good for an individual, whereas more negatively reciprocal individuals fare worse. Notably, the impact of reciprocity on the ability to sustain friendship relationships is consistent with our previous findings on how reciprocity affects the probability of being in another type of relationship, i.e., being employed.

We next turn to a financial measure of success. Columns (2) and (3) of Table 4 present

\footnotetext{
12 The question about close friends was asked in the 2003 wave, so the regression includes only those individuals who were also in the survey in 2003. Results are qualitatively similar if we use a Tobit model instead of OLS.
} 
regressions where the dependent variable is an individual's log gross monthly labor income. Column (2) includes the two reciprocity measures, and the standard controls typically used in Mincer wage regressions: Years of education, experience, experience squared, and a full set of occupational and sectoral controls. The regression also includes a gender dummy. The results are in line with the results usually found in such earnings regressions, with a return to schooling of around 2.5 percent, larger returns to experience, and a higher income for longer hours worked. Most interestingly, positive reciprocity is associated with significantly higher income levels, while negative reciprocity has no effect on income. Although positively reciprocal individuals earn higher incomes, this effect is apparently explained by higher effort, in the form of more hours worked. This can be seen in column (3), where adding a control for weekly hours causes the coefficient for positive reciprocity to become substantially smaller and statistically insignificant. Using log gross hourly wages as the dependent variable, constructed based on actual working hours, instead of log monthly income, we also find no effect of reciprocity. The fact that positively reciprocal individuals are paid more, but also work harder, is again consistent with laboratory evidence showing that workers reciprocate for higher wages by working harder.

Perhaps the ultimate measure of success for an individual is how satisfied they are, subjectively, with their own life. We use a standard measure of life satisfaction, asking the individual to rate satisfaction with their life on an 11-point scale, where 0 indicates "absolutely unsatisfied" and 10 indicates "absolutely satisfied". Column (4) in Table 4 reports a regression where life satisfaction is the dependent variable. Life satisfaction is measured on an 11-point scale, from "completely dissatisfied" to "completely satisfied." To account for the fact that the dependent variable is measured in intervals, and thus is left and right censored, coefficients are based on interval regression. The results are striking: Individuals with a high level of positive reciprocal attitudes report to be more satisfied with their life, while negative reciprocity tends to make individuals less satisfied with their life. Notably, the additional controls all have the effects typically found in lifesatisfaction regressions (see, e.g., van Praag and Ferrer-i-Carbonell, 2004). For example, women and older individuals tend to be more satisfied with their lives, marriage has a strong positive effect, and divorce significantly decreases life satisfaction. As is typically the case, unemployment and a bad health status have the largest negative effects on life satisfaction of all controls. Higher education, reflected by having passed the (Abitur) exam, makes individuals more satisfied, and income has a significant positive effect on subjective well-being. ${ }^{13}$ Note that the effects of reciprocity on happiness are quite large.

13 The income variable is logged and comprises all sources of income, including non-labor income and 
They are in the same order of magnitude as the gender effect or being married.

\section{Concluding remarks}

In this paper we have shown that most people in the population characterize themselves as positively or negatively reciprocal. We find that gender, age and height systematically affect reciprocal inclination but differently for positive and negative reciprocity. This suggests that there is no underlying notion of in-kind behavior but rather a distinct disposition to be either positively or negatively reciprocal. This finding is corroborated by the fact that positive and negative reciprocity affect economic outcomes in an asymmetric way: Being positively reciprocal predicts higher subjective well-being, higher wages and lower unemployment and also higher work effort, as measured, e.g., in terms of overtime hours. Negative reciprocity on the other hand is associated with lower levels of happiness, higher unemployment and higher frequency of absenteeism.

Our findings add to the understanding of reciprocity, which is probably the most important type of social preferences. The overwhelming support in particular for the notion of positive reciprocity calls for an intensified investigation of the economic consequences of reciprocity, e.g., for labor relations and social policy issues (Bowles and Gintis, 1998).

For example, policies that reward people independent on their contribution to society will most likely be less supported by the public than policies that account for reciprocal considerations. As an example, take the debate about workfare vs. welfare. Unlike regular public assistance, workfare requires recipients to spend time on mandatory activities such as community work. In the presence of reciprocally motivated taxpayers we would expect that support in favor of workfare programs is more pronounced than often assumed. The existence of reciprocity also offers new channels for policy interventions, e.g., in the context of tax evasion. The typical policy recommendation based on purely selfish individuals argues that tax evasion can be reduced by either increasing fines or detection probabilities. Reciprocity offers an additional perspective. If taxpayers are reciprocal, i.e., conditionally cooperative they are more willing to pay taxes if the tax system is considered as fair and if other tax payers are expected to pay their taxes as well. The latter argument suggests the existence of two types of equilibria, a good one where people pay taxes and expect others to pay taxes and a bad one where people don't pay taxes in the expectation that others don't pay their taxes as well. Tax policy could try to reach good equilibria with the help

social support. The results are similar when using a linear specification, or restricting attention to labor income only. 
of expectation management and improving the perceived fairness of the tax system. 


\section{References}

Abbink, K., B. Irlenbusch, and E. Renner (2000): "The Moonlighting Game: An Experimental Study on Reciprocity and Retribution," Journal of Economic Behavior and Organization, 42, $265-277$.

Akerlof, G. (1982): "Labor Contracts as a Partial Gift Exchange," Quarterly Journal of Economics, 97, 543 - 569 .

Bellemare, C., and S. Kröger (2005): “On Representative Social Capital," CIRPEE Working Paper.

Berg, J., J. Dickhaut, and K. McCabe (1995): "Trust, Reciprocity and Social History," Games and Economic Behaviour, 10, 122 - 142.

Bewely, T. (1999): Why Wages Don't Fall During Recessions. Cambridge University Press, Cambridge, MA.

Bowles, S., And H. Gintis (2002): “The Inheritance of Inequality,” Journal of Economic Perspectives, 16(3), 3-30.

(2004): "The Evolution of Strong Reciprocity: Cooperation in Heterogeneous Populations," Theoretical Population Biology, 65, 17-28.

Burnham, T. (1999): "Testosterone and Negotiations," mimeo, John F. Kennedy School of Government, Harvard University.

Camerer, C., and R. Hogarth (1999): "The Effects of Financial Incentives in Experiments: A Review and Capital-Labor-Production Framework," Journal of Risk and Uncertainty, 19(1), 7-42.

Camerer, C., and R. Thaler (1995): "Ultimatums, Dictators, and Manners," Journal of Economic Perspectives, 9, 209-219.

Carpenter, J., And E. Seki (2005): "Do Social Preferences Increase Productivity? Field experimental evidence from fishermen in Toyama Bay," mimeo, Middlebury College.

Croson, R., and U. Gneezy (2004): "Gender Differences in Preferences," mimeo, Graduate School of Business, University of Chicago.

Dohmen, T., A. Falk, D. Huffman, U. Sunde, J. Schupp, and W. Wagner (2005): "Individual Risk Attitudes: New Evidence From a Large, Representative, Experimentally-Validated Survey," IZA Discussion Paper, 1730.

FAlK, A. (2006): "Gift-exchange in the Field," IZA Discussion Paper, 1148.

Falk, A., and U. Fischbacher (2006): "A Theory of Reciprocity," Games and Economic Behavior, 54(2), 293-315.

Falk, A., And C. Zehnder (2006): "Trust and Discrimination - A Citywide Experiment," IZA Working Paper.

Fehr, E., And A. Falk (1999): "Wage Rigidities in a Competitive Incomplete Contract Market. An Experimental Investigation," Journal of Political Economy, 107(1), 106134 . 
Fehr, E., U. Fischbacher, B. v. Rosenbladt, J. Schupp, and G. G. Wagner (2003): "A Nation-Wide Laboratory: Examining Trust and Trustworthiness by Integrating Behavioral Experiments into Representative Surveys," mimeo, Institute for Empirical Research in Economics, University of Zurich.

Fehr, E., ANd S. Gächter (2000): "Fairness and Retaliation," Journal of Economic Perspectives, 14(3), 159-181.

— (2002): "Altruistic Punishment in Humans," Nature, 415, 137-140.

Fehr, E., G. Kirchsteiger, and A. Riedl (1993): "Does Fairnes Prevent Market Clearing? An Experimental Investigation," Quarterly Journal of Economics, 108, 437460.

Ferrer-i Carbonell, A., and P. Frijters (2004): "How Important is Methodology for the Estimates of the Determinants of Happiness?," Economic Journal, 114, 641-659.

Frey, B., And A. Stutzer (2002): "What Can Economists Learn from Happiness Research?," Journal of Economic Literature, 40, 402 - 435.

Frijters, P., J. P. Haisken-Denew, and M. A. Shields (2004a): "Money Does Matter! Evidence from Increasing Real Incomes and Life Satisfaction in East Germany Following Reunification," American Economic Review, 94(3), 730 - 740.

(2004b): "Investigating the Patterns and Determinants of Life Satisfaction in Germany following Reunification," Journal of Human Resources, 39(3), 649-674.

Gächter, S., and B. Herrmann (2006): "The Limits of Self-Governance in the Presence of Spite: Experimental Evidence from Urban and Rural Russia," University of Nottingham.

Gneezy, U. (2003): "Do High Wages Lead to High Profits? An Experimental Study of Reciprocity Using Real Effort," Discussion paper University of Chicago.

Güth, W., R. Schmittberger, and B. Schwarze (1982): "An Experimental Analysis of Ultimatum Bargaining," Journal of Economic Behavior and Organization, 3, 367388.

Heckman, J. J., And Y. Rubinstein (2001): "The Importance of Noncognitive Skills: Lessons from the GED Testing Program," American Economic Review, 91(2), 149-149.

Heckman, James J., S. J., and S. Uzrua (2006): "Investing in Disadvantaged Young Children is an Economically Efficient Policy," NBER Working Paper No. W12006.

Krueger, A., And A. Mas (2004): "Strikes, Scabs and Tread Separations: Labor Strife and the Production of Defective Bridgestone/Firestone Tires," Journal of Political Economy, 112(2), 253-289.

Osborne, M. (2005): Personality and the Intergenerational Transmission of Economic Status. Princeton University Press, Princeton.

Persico, N., A. Postlewaite, and D. Silverman (2004): "The Effect of Adolescence Experience on Labor Market Outcomes: The Case of Height," Journal of Political Economy, 112(5), 1019-1053. 
Quervaine, D., U. Fischbacher, V. Treyer, M. Schellhammer, U. Schnyder, A. Buck, and E. Fehr (2004): "The Neural Basis of Altruistic Punishment," Science, $305,1254-1258$.

Schupp, J., And G. G. Wagner (2002): "Maintenance of and Innovation in Long-Term Panel Studies The Case of the German Socio-Economic Panel (GSOEP)," Allgemeines Statistisches Archiv, 86(2), 163-175.

van PraAg, B. M. S., and A. Ferrer-I Carbonell (2004): Happiness Quantified A Satisfaction Calculus Approach. Oxford University Press, Oxford.

Wagner, G. G., R. V. Burkhauser, and F. Behringer (1993): "The English Language Public Use File of the German Socio-Economic Panel," The Journal of Human Resources, 28(2), 429-433. 
Tables 
Table 1: Primary Determinants of Reciprocity

\begin{tabular}{lcccc}
\hline \hline Dependent Variable: & \multicolumn{2}{c}{ Positive Reciprocity } & \multicolumn{2}{c}{ Negative Reciprocity } \\
& $(1)$ & $(2)$ & $(3)$ & $(4)$ \\
\hline \multirow{3}{*}{ Female } & & & & \\
& $0.040^{* *}$ & $0.037^{*}$ & $-0.378^{* * *}$ & $-0.340^{* * *}$ \\
Age (in years) & {$[0.017]$} & {$[0.020]$} & {$[0.027]$} & {$[0.031]$} \\
& $0.003^{* * *}$ & $0.003^{* * *}$ & $-0.011^{* * *}$ & $-0.017^{* * *}$ \\
Height (in cm) & {$[0.000]$} & {$[0.001]$} & {$[0.001]$} & {$[0.001]$} \\
& $0.003^{* * *}$ & $0.003^{* *}$ & -0.001 & 0.002 \\
Constant & {$[0.001]$} & {$[0.001]$} & {$[0.002]$} & {$[0.002]$} \\
& $5.138^{* * *}$ & $5.998^{* * *}$ & $3.967^{* * *}$ & $4.132^{* * *}$ \\
Other Controls & {$[0.199]$} & {$[0.258]$} & {$[0.311]$} & {$[0.608]$} \\
\hline \multirow{3}{*}{ Observations } & No & Yes & No & Yes \\
R-squared & 19,821 & 16,826 & 19,769 & 16,784 \\
\hline \hline
\end{tabular}

OLS coefficient estimates. The dependent variable in columns (1) and (2) is a measure for positive reciprocity, reflecting the average agreement to three statements concerning, respectively, willingness to return a favor, to go out of the way to help somebody who was kind, and undergo personal costs to help someone who was helpful before. The dependent variable in columns (3) and (4) is a measure for negative reciprocity, reflecting the average agreement statements concerning willingness to take revenge for a serious wrong, to retaliate for being put in a difficult position, and respond to an insult with an insult. Answers are always on a scale from 1 to 7 , where 1 means "does not apply to me at all" and 7 means "applies to me perfectly". Additional controls include parental education (completed Abitur exam), marital status, number of children in household, religious background, social and national background, occupational and sectoral information, educational background and month of interview. For detailed results see Table A.1 in the appendix. Robust standard errors in brackets allow for clustering at the household level; ***, **,* indicate significance at 1-, 5-, and 10-percent level, respectively. 
Table 2: Reciprocity and Work Effort

\begin{tabular}{|c|c|c|c|c|c|}
\hline \multirow[t]{2}{*}{ Dependent Variable: } & \multirow{2}{*}{$\begin{array}{c}\text { Actual Weekly } \\
\text { Hours Worked } \\
(1) \\
\end{array}$} & \multirow{2}{*}{$\begin{array}{c}\text { Worked Overtime } \\
\text { last Month } \\
(2)\end{array}$} & \multirow{2}{*}{$\begin{array}{c}\text { Hours Overtime } \\
\text { last Month } \\
(3)\end{array}$} & \multicolumn{2}{|c|}{ Days of Sickleave } \\
\hline & & & & $\begin{array}{c}\text { in } 2003 \\
(4)\end{array}$ & $\begin{array}{c}\text { in } 2004 \\
(5)\end{array}$ \\
\hline \multirow[t]{2}{*}{ Positive Reciprocity } & $0.222^{* *}$ & $0.021^{* * *}$ & $0.161^{* * *}$ & -0.173 & -0.058 \\
\hline & {$[0.111]$} & {$[0.007]$} & {$[0.037]$} & {$[0.386]$} & {$[0.456]$} \\
\hline \multirow{2}{*}{ Negative Reciprocity } & -0.032 & $-0.012^{* * *}$ & $-0.047^{*}$ & $0.432^{*}$ & $0.514^{*}$ \\
\hline & {$[0.068]$} & {$[0.004]$} & {$[0.024]$} & {$[0.240]$} & {$[0.283]$} \\
\hline \multirow{2}{*}{ Bad Subjective Health Status } & & & & $5.693^{* * *}$ & $7.586^{* * *}$ \\
\hline & & & & {$[0.421]$} & {$[0.496]$} \\
\hline \multirow[t]{2}{*}{ Log Gross Monthly Income } & $10.297 * * *$ & $0.184^{* * *}$ & $0.622^{* * *}$ & $4.472^{* * *}$ & $9.963^{* * *}$ \\
\hline & [0.190] & {$[0.010]$} & {$[0.041]$} & {$[0.601]$} & {$[0.762]$} \\
\hline \multirow{2}{*}{ Years of Education } & $-0.429 * * *$ & -0.002 & -0.013 & $-0.563^{* * *}$ & $-0.675^{* * *}$ \\
\hline & [0.049] & {$[0.003]$} & {$[0.017]$} & {$[0.168]$} & {$[0.199]$} \\
\hline \multirow[t]{2}{*}{ Experience } & $-0.212^{* * *}$ & -0.0001 & 0.011 & -0.102 & -0.013 \\
\hline & [0.038] & {$[0.002]$} & {$[0.011]$} & {$[0.134]$} & {$[0.159]$} \\
\hline \multirow[t]{2}{*}{ Experience $^{2} / 100$} & $0.149^{* *}$ & $-0.010^{* *}$ & $-0.051^{* *}$ & -0.219 & $-0.601^{*}$ \\
\hline & {$[0.075]$} & {$[0.005]$} & {$[0.021]$} & {$[0.265]$} & {$[0.319]$} \\
\hline \multirow[t]{2}{*}{ Female } & $-3.843^{* * *}$ & $-0.022^{*}$ & $-0.550 * * *$ & $3.110^{* * *}$ & $5.571^{* * *}$ \\
\hline & {$[0.232]$} & {$[0.013]$} & {$[0.071]$} & {$[0.811]$} & {$[0.956]$} \\
\hline \multirow[t]{2}{*}{ Constant } & $-30.584^{* * *}$ & & $-2.984^{* * *}$ & $-44.619^{* * *}$ & $-103.135^{* * *}$ \\
\hline & [1.773] & & {$[0.481]$} & {$[5.751]$} & {$[7.112]$} \\
\hline Occupational Controls & Yes & Yes & Yes & Yes & Yes \\
\hline Observations & 9662 & 8941 & 9856 & 8345 & 8896 \\
\hline (Pseudo-)R-squared & 0.53 & 0.09 & 0.14 & 0.01 & 0.02 \\
\hline
\end{tabular}

The dependent variable in column (1) is the answer to questions on regular average weekly working time including overtime, entries are OLS coefficient estimates. The dependent variable in column (2) is a binary variable, taking the value 1 if an individual reports to have worked overtime in the past month, entries are binary Probit marginal effects. The dependent variable in column (3) is the number of hours of overtime an individual reports having worked during the last month, converted into hours per week. Entries are Tobit coefficient estimates. The dependent variable in columns (4) and (5) is the total number of days absent from work due to illness in 2003 and 2004, respectively. The variable is censored at zero, estimates are Tobit coefficients. The control for gross labor income refers to income in the previous month, excluding bonuses and extra payments, but including remuneration for overtime. The measure of positive reciprocity is the individual's average level of agreement to three statements concerning, respectively, willingness to return a favor, to go out of the way to help somebody who was kind, and undergo personal costs to help someone who was helpful before. The measure of negative reciprocity reflects average agreement to statements concerning willingness to take revenge for a serious wrong, to retaliate for being put in a difficult position, and to respond to an insult with an insult. Answers are always on a scale from 1 to 7 , where 1 means "does not apply to me at all" and 7 means "applies to me perfectly". For detailed results including occupational controls see Table A.4 in the appendix. Robust standard errors in brackets allow for clustering at the household level; ${ }^{* *}, * *, *$ indicate significance at 1-, 5-, and 10-percent level, respectively. 
Table 3: Reciprocity and Unemployment

\begin{tabular}{lc}
\hline \hline Dependent Variable: & $\begin{array}{c}1 \text { if } \begin{array}{c}(1) \\
\end{array} \\
\text { Positive Reciprocity }\end{array}$ \\
Negative Reciprocity & $-0.010^{* * *}$ \\
& $0.003]$ \\
Years of Education & {$[0.002]$} \\
& $-0.018^{* * * *}$ \\
1 if female & {$[0.001]$} \\
& 0.001 \\
Age (in Years) & {$[0.005]$} \\
& $0.002^{* * *}$ \\
Lived in GDR in 1989 & {$[0.000]$} \\
& $0.089^{* * *}$ \\
Lived abroad in 1989 & {$[0.009]$} \\
& $0.061^{* * *}$ \\
Residence in 1989 missing & {$[0.018]$} \\
German Nationality & 0.035 \\
& {$[0.036]$} \\
Observations & $-0.033^{* *}$ \\
\hline \hline
\end{tabular}

Probit marginal effects estimates. The dependent variable takes the value 1 if the respondent is unemployed. The measure of positive reciprocity is the individual's average level of agreement to three statements concerning, respectively, willingness to return a favor, to go out of the way to help somebody who was kind, and undergo personal costs to help someone who was helpful before. The measure of negative reciprocity reflects average agreement to statements concerning willingness to take revenge for a serious wrong, to retaliate for being put in a difficult position, and to respond to an insult with an insult. Answers are always on a scale from 1 to 7 , where 1 means "does not apply to me at all" and 7 means "applies to me perfectly". Additional controls are marital status, number of children in the household, and religious background. Robust standard errors in brackets allow for clustering at the household level; ${ }^{* * *},{ }^{* *}, *$ indicate significance at 1-, 5-, and 10-percent level, respectively. 
Table 4: Success of Homo Reciprocans

\begin{tabular}{|c|c|c|c|c|}
\hline \multirow[t]{2}{*}{ Dependent Variable: } & \multirow{2}{*}{$\begin{array}{l}\text { Number of Friends } \\
\text { (1) }\end{array}$} & \multicolumn{2}{|c|}{ Log Income } & \multirow{2}{*}{$\begin{array}{l}\text { Overall Life Satisfaction } \\
\text { (4) }\end{array}$} \\
\hline & & $(2)$ & $(3)$ & \\
\hline \multirow[t]{2}{*}{ Positive Reciprocity } & $0.217^{* * *}$ & $0.020 * * *$ & 0.005 & $0.172^{* * *}$ \\
\hline & {$[0.039]$} & {$[0.008]$} & {$[0.006]$} & {$[0.016]$} \\
\hline \multirow[t]{2}{*}{ Negative Reciprocity } & $-0.078^{* * *}$ & 0.006 & 0.004 & $-0.103^{* * *}$ \\
\hline & {$[0.027]$} & {$[0.005]$} & {$[0.004]$} & [0.010] \\
\hline \multirow[t]{2}{*}{ Years of Education } & $0.098 * * *$ & $0.015^{* * *}$ & $0.023^{* * *}$ & $0.023^{* * *}$ \\
\hline & {$[0.017]$} & {$[0.004]$} & {$[0.003]$} & {$[0.006]$} \\
\hline \multirow[t]{2}{*}{ Experience } & & $0.047^{* * *}$ & $0.039^{* * *}$ & \\
\hline & & [0.003] & {$[0.002]$} & \\
\hline \multirow[t]{2}{*}{ Experience $^{2}$} & & $-0.001^{* * *}$ & $-0.001^{* * *}$ & \\
\hline & & [0.000] & {$[0.000]$} & \\
\hline \multirow[t]{2}{*}{ Female } & -0.051 & $-0.529 * * *$ & $-0.222 * * *$ & $0.141^{* * *}$ \\
\hline & {$[0.095]$} & {$[0.015]$} & {$[0.013]$} & {$[0.036]$} \\
\hline \multirow[t]{2}{*}{ Actual Weekly Hours } & & & $0.032^{* * *}$ & \\
\hline & & & {$[0.001]$} & \\
\hline \multirow[t]{2}{*}{ Age (in years) } & 0.004 & & & $0.009 * * *$ \\
\hline & {$[0.005]$} & & & {$[0.002]$} \\
\hline \multirow[t]{2}{*}{ Married } & -0.154 & & & $0.204^{* * *}$ \\
\hline & {$[0.119]$} & & & {$[0.046]$} \\
\hline \multirow{2}{*}{ Divorced } & $-0.739 * * *$ & & & $-0.216^{* * *}$ \\
\hline & [0.163] & & & {$[0.067]$} \\
\hline \multirow[t]{2}{*}{ Widowed } & $-0.666^{* * *}$ & & & -0.028 \\
\hline & {$[0.208]$} & & & {$[0.076]$} \\
\hline \multirow[t]{2}{*}{ Lived in GDR in 1989} & -0.046 & & & $-0.522^{* * *}$ \\
\hline & {$[0.109]$} & & & [0.039] \\
\hline \multirow[t]{2}{*}{ Lived abroad in 1989} & $-0.528^{* *}$ & & & -0.076 \\
\hline & {$[0.226]$} & & & {$[0.082]$} \\
\hline \multirow{2}{*}{ Residence in 1989 missing } & $-1.177^{* * *}$ & & & $-0.515^{* * *}$ \\
\hline & {$[0.425]$} & & & {$[0.165]$} \\
\hline \multirow[t]{2}{*}{ Unemployed } & -0.07 & & & $-1.120 * * *$ \\
\hline & {$[0.175]$} & & & {$[0.077]$} \\
\hline \multirow[t]{2}{*}{ Non-Participating } & 0.02 & & & 0.043 \\
\hline & {$[0.169]$} & & & {$[0.067]$} \\
\hline \multirow[t]{2}{*}{ Retired (Pension) } & 0.101 & & & $0.152^{* *}$ \\
\hline & {$[0.169]$} & & & {$[0.060]$} \\
\hline \multirow[t]{2}{*}{ Bad Subjective Health Status } & $-0.167 * * *$ & & & $-0.851^{* * *}$ \\
\hline & {$[0.043]$} & & & {$[0.017]$} \\
\hline \multirow[t]{2}{*}{ Log Monthly Income } & -0.015 & & & $0.016^{* *}$ \\
\hline & {$[0.017]$} & & & {$[0.006]$} \\
\hline \multirow[t]{2}{*}{ Constant } & 3.316 & $7.040^{* * *}$ & $5.692^{* * *}$ & $6.048^{* * *}$ \\
\hline & {$[2.712]$} & {$[0.077]$} & {$[0.068]$} & {$[0.548]$} \\
\hline Other Controls & Yes & & & Yes \\
\hline Occupational Controls & Yes & Yes & Yes & Yes \\
\hline Observations & 15704 & 9856 & 9662 & 16698 \\
\hline R-squared & 0.03 & 0.49 & 0.66 & \\
\hline
\end{tabular}

OLS coefficient estimates in Columns (1) to (3). The dependent variable in Column (1) is the number of close friends and is constructed based on the answer to a question in the 2003 wave. The dependent variable in Columns (2) and (3) is log gross labor income (based on a question asking about the previous month), excluding bonuses and extra payments, but including remuneration for overtime. The dependent variable in Column (4) is the answer to a question on overall life satisfaction on a scale from 0 to 10 , where 0 means "completely dissatisfied" and 10 means "completely satisfied". Because the dependent variable is elicited in intervals, coefficients are based on interval regression, which corrects for left and right censoring of the dependent variable. The measure of positive reciprocity is the individual's average level of agreement to three statements concerning, respectively, willingness to return a favor, to go out of the way to help somebody who was kind, and undergo personal costs to help someone who was helpful before. The measure of negative reciprocity reflects average agreement to statements concerning willingness to take revenge for a serious wrong, to retaliate for being put in a difficult position, and to respond to an insult with an insult. Answers are always on a scale from 1 to 7 , where 1 means "does not apply at all" and 7 means "totally applies". For detailed results including occupatignal controls see Table A.3 in the appendix. Additional controls are parental background, marital status, number of children in household, religious background, social and national background, income (including non-labor income, social support, unemployment insurance and any other support) and month of interview. For detailed results see Table A.2 in the appendix. Robust standard errors in brackets allow for clustering at the household level; ***, **,* indicate significance at 1-, 5-, and 10-percent level, respectively. 

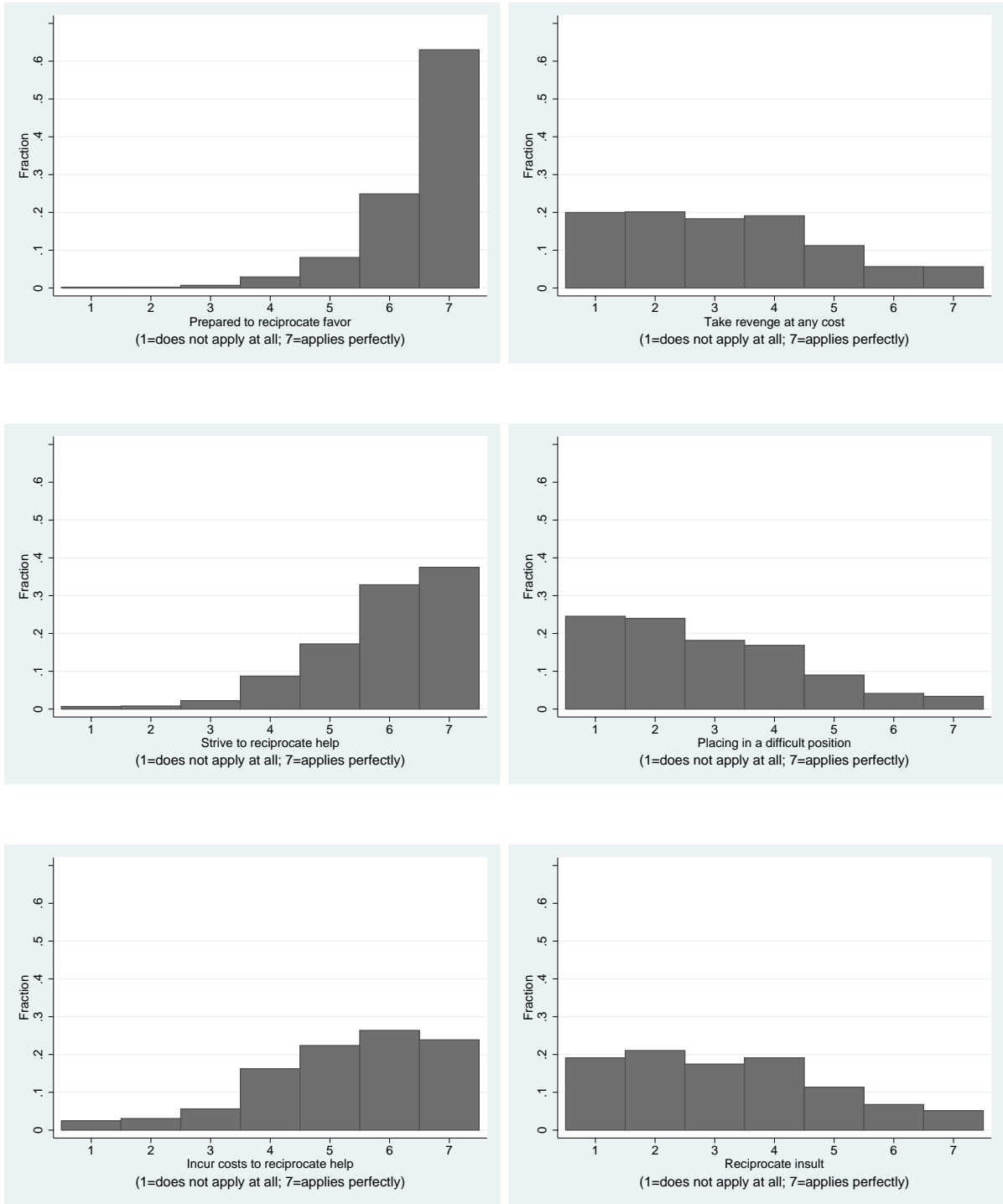

Notes: The histograms show the distributions of responses to each of the six reciprocity measures. Positive reciprocity measures are shown in the left-hand column, negative in the right. The positive reciprocity measures asked whether the respondent is the type of person who: returns a favor; goes out of the way to help somebody who was kind; undergoes personal costs to help someone who was helpful before. The negative reciprocity measures asked whether the individual is someone who: takes revenge no matter what the cost, after a serious wrong; retaliates for being put in a difficult position by doing the same; responds to an insult with an insult. Answers are on a scale from 1 to 7 , where 1 means "does not apply to me at all" and 7 means "applies to me perfectly". 
Figure 2: Distribution of Reciprocity
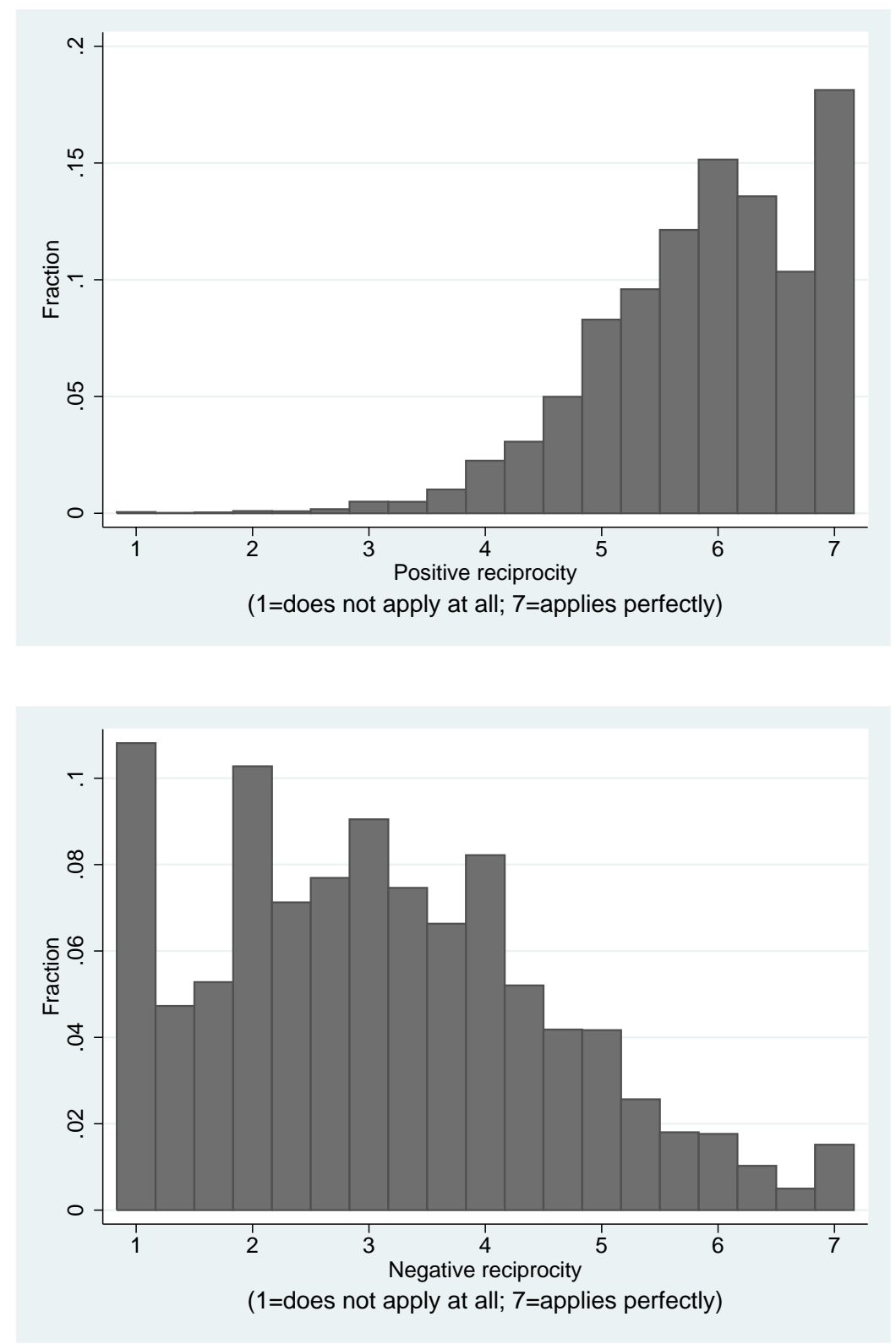

Notes: The histograms show the distributions of positive and negative reciprocity in the representative sample. For each individual, the degree of positive reciprocity is calculated by taking the simple average of responses to the three positive reciprocity measures. Negative reciprocity is based on the average across the three negative reciprocity measures. 
A Appendix 
Table A.1: Primary Determinants of Reciprocity

\begin{tabular}{|c|c|c|c|c|}
\hline \multirow[t]{2}{*}{ Dependent Variable: } & \multicolumn{2}{|c|}{ Positive Reciprocity } & \multicolumn{2}{|c|}{ Negative Reciprocity } \\
\hline & (1) & $(2)$ & $(3)$ & $(4)$ \\
\hline Female & $\begin{array}{c}0.040^{* *} \\
{[0.017]}\end{array}$ & $\begin{array}{l}0.037^{*} \\
{[0.020]}\end{array}$ & $\begin{array}{c}-0.378^{* * *} \\
{[0.027]}\end{array}$ & $\begin{array}{c}-0.340 * * * \\
{[0.031]}\end{array}$ \\
\hline Age (in years) & $\begin{array}{c}0.003^{* * *} \\
{[0.000]}\end{array}$ & $\begin{array}{c}0.003^{* * *} \\
{[0.001]}\end{array}$ & $\begin{array}{c}-0.011 * * * \\
{[0.001]}\end{array}$ & $\begin{array}{c}-0.017 * * * \\
{[0.001]}\end{array}$ \\
\hline Height (in $\mathrm{cm}$ ) & $\begin{array}{c}0.003^{* * *} \\
{[0.001]}\end{array}$ & $\begin{array}{l}0.003^{* *} \\
{[0.001]}\end{array}$ & $\begin{array}{l}-0.001 \\
{[0.002]}\end{array}$ & $\begin{array}{c}0.002 \\
{[0.002]}\end{array}$ \\
\hline Abitur Mother & & $\begin{array}{c}-0.01 \\
{[0.031]}\end{array}$ & & $\begin{array}{l}-0.082^{*} \\
{[0.049]}\end{array}$ \\
\hline Abitur Father & & $\begin{array}{l}0.042^{*} \\
{[0.024]}\end{array}$ & & $\begin{array}{l}-0.036 \\
{[0.037]}\end{array}$ \\
\hline Married & & $\begin{array}{c}0.055^{* *} \\
{[0.026]}\end{array}$ & & $\begin{array}{l}-0.004 \\
{[0.041]}\end{array}$ \\
\hline Divorced & & $\begin{array}{l}0.065^{*} \\
{[0.036]}\end{array}$ & & $\begin{array}{l}-0.052 \\
{[0.056]}\end{array}$ \\
\hline Widowed & & $\begin{array}{c}0.047 \\
{[0.043]}\end{array}$ & & $\begin{array}{l}-0.082 \\
{[0.065]}\end{array}$ \\
\hline 1 Child born after 1987 & & $\begin{array}{l}-0.023 \\
{[0.025]}\end{array}$ & & $\begin{array}{l}-0.06 \\
{[0.040]}\end{array}$ \\
\hline 2 Children born after 1987 & & $\begin{array}{c}-0.093^{* * *} \\
{[0.029]}\end{array}$ & & $\begin{array}{l}-0.069 \\
{[0.045]}\end{array}$ \\
\hline 3 Children born after 1987 & & $\begin{array}{l}-0.018 \\
{[0.047]}\end{array}$ & & $\begin{array}{c}-0.205^{* *} \\
{[0.083]}\end{array}$ \\
\hline > 3 Children born after 1987 & & $\begin{array}{c}-0.193^{*} \\
{[0.107]}\end{array}$ & & $\begin{array}{c}-0.424^{* * *} \\
{[0.148]}\end{array}$ \\
\hline Catholic & & $\begin{array}{l}-0.029 \\
{[0.020]}\end{array}$ & & $\begin{array}{l}0.058^{*} \\
{[0.031]}\end{array}$ \\
\hline Other Christian confession & & $\begin{array}{l}-0.002 \\
{[0.062]}\end{array}$ & & $\begin{array}{c}-0.367^{* * *} \\
{[0.098]}\end{array}$ \\
\hline Not religious & & $\begin{array}{c}0.002 \\
{[0.057]}\end{array}$ & & $\begin{array}{l}-0.086 \\
{[0.095]}\end{array}$ \\
\hline No confession & & $\begin{array}{l}-0.015 \\
{[0.022]}\end{array}$ & & $\begin{array}{c}0.186^{* * *} \\
{[0.034]}\end{array}$ \\
\hline Missing Religion & & $\begin{array}{l}-0.051 \\
{[0.045]}\end{array}$ & & $\begin{array}{c}0.269 * * * \\
{[0.072]}\end{array}$ \\
\hline Lived in GDR in 1989 & & $\begin{array}{c}0.022 \\
{[0.022]}\end{array}$ & & $\begin{array}{c}-0.078^{* *} \\
{[0.034]}\end{array}$ \\
\hline Lived abroad in 1989 & & $\begin{array}{c}0.112^{* * *} \\
{[0.042]}\end{array}$ & & $\begin{array}{c}-0.347^{* * *} \\
{[0.073]}\end{array}$ \\
\hline Residence in 1989 missing & & $\begin{array}{c}0 \\
{[0.089]}\end{array}$ & & $\begin{array}{c}-0.387 * * * \\
{[0.142]}\end{array}$ \\
\hline German Nationality & & $\begin{array}{c}-0.099^{* *} \\
{[0.039]}\end{array}$ & & $\begin{array}{c}-0.135^{* *} \\
{[0.066]}\end{array}$ \\
\hline Enrolled in School/College/University & & $\begin{array}{c}-0.201 * * * \\
{[0.051]}\end{array}$ & & $\begin{array}{c}-0.201 * * * \\
{[0.075]}\end{array}$ \\
\hline
\end{tabular}


Table A.1: continued: Determinants of Reciprocity

\begin{tabular}{|c|c|c|}
\hline Dependent Variable: & $\begin{array}{l}\text { Positive Reciprocity } \\
(1)\end{array}$ & $\begin{array}{l}\text { Negative Reciprocity } \\
(3) \quad(4)\end{array}$ \\
\hline \multicolumn{3}{|l|}{ Public Sector: } \\
\hline Unskilled Blue Collar & $\begin{array}{c}0.137 \\
{[0.118]}\end{array}$ & $\begin{array}{c}0.152 \\
{[0.210]}\end{array}$ \\
\hline Skilled Blue Collar & $\begin{array}{l}-0.018 \\
{[0.092]}\end{array}$ & $\begin{array}{c}0.128 \\
{[0.164]}\end{array}$ \\
\hline Blue Collar Craftsman & $\begin{array}{l}0.140^{*} \\
{[0.076]}\end{array}$ & $\begin{array}{c}0.301^{* *} \\
{[0.150]}\end{array}$ \\
\hline Blue Collar Foreman & $\begin{array}{l}-0.035 \\
{[0.347]}\end{array}$ & $\begin{array}{c}0.609 \\
{[0.603]}\end{array}$ \\
\hline Blue Collar Master & $\begin{array}{l}-0.133 \\
{[0.139]}\end{array}$ & $\begin{array}{c}0.014 \\
{[0.350]}\end{array}$ \\
\hline Unskilled White Collar & $\begin{array}{l}-0.063 \\
{[0.109]}\end{array}$ & $\begin{array}{l}-0.125 \\
{[0.172]}\end{array}$ \\
\hline Skilled White Collar & $\begin{array}{l}-0.053 \\
{[0.074]}\end{array}$ & $\begin{array}{c}-0.227^{* *} \\
{[0.100]}\end{array}$ \\
\hline White Collar Technician & $\begin{array}{l}{[0.074]} \\
-0.05 \\
{[0.041]}\end{array}$ & $\begin{array}{c}-0.173^{* * *} \\
{[0.061]}\end{array}$ \\
\hline Highly-Skilled White Collar & $\begin{array}{c}0.011] \\
0.017 \\
{[0.048]}\end{array}$ & $\begin{array}{c}{[0.001]} \\
-0.134^{*} \\
{[0.077]}\end{array}$ \\
\hline White Collar Management & $\begin{array}{l}-0.039 \\
{[0.206]}\end{array}$ & $\begin{array}{c}0.03 \\
{[0.357]}\end{array}$ \\
\hline Civil Servant & $\begin{array}{l}-0.052 \\
{[0.224]}\end{array}$ & $\begin{array}{l}-0.159 \\
{[0.341]}\end{array}$ \\
\hline Civil Servant Intermediate & $\begin{array}{l}-0.087 \\
{[0.069]}\end{array}$ & $\begin{array}{c}0.01 \\
{[0.103]}\end{array}$ \\
\hline Civil Servant High & $\begin{array}{l}-0.084 \\
{[0.051]}\end{array}$ & $\begin{array}{c}-0.161^{* *} \\
{[0.075]}\end{array}$ \\
\hline Civil Servant Executive & {$\left[\begin{array}{l}-0.074 \\
{[0.059]}\end{array}\right.$} & $\begin{array}{l}-0.138 \\
{[0.090]}\end{array}$ \\
\hline Private Sector: & & \\
\hline Unskilled Blue Collar & $\begin{array}{l}-0.018 \\
{[0.055]}\end{array}$ & $\begin{array}{l}0.179^{*} \\
{[0.095]}\end{array}$ \\
\hline Skilled Blue Collar & $\begin{array}{l}-0.009 \\
{[0.042]}\end{array}$ & $\begin{array}{l}0.165^{* *} \\
{[0.070]}\end{array}$ \\
\hline Blue Collar Craftsman & $\begin{array}{l}-0.009 \\
{[0.038]}\end{array}$ & $\begin{array}{c}0.092 \\
{[0.063]}\end{array}$ \\
\hline Blue Collar Foreman & $\begin{array}{c}0.185^{* * *} * \\
{[0.066]}\end{array}$ & $\begin{array}{l}0.246^{*} \\
{[0.129]}\end{array}$ \\
\hline Blue Collar Master & $\begin{array}{l}-0.022 \\
{[0.088]}\end{array}$ & $\begin{array}{c}-0.248^{* *} \\
{[0.121]}\end{array}$ \\
\hline Unskilled White Collar & $\begin{array}{l}-0.073 \\
{[0.056]}\end{array}$ & $\begin{array}{l}-0.012 \\
{[0.088]}\end{array}$ \\
\hline White Collar Technician & $\begin{array}{c}0.045 \\
{[0.043]}\end{array}$ & $\begin{array}{c}0.04 \\
{[0.069]}\end{array}$ \\
\hline Highly-Skilled White Collar & $\begin{array}{l}-0.062^{*} \\
{[0.036]}\end{array}$ & $\begin{array}{l}-0.062 \\
{[0.056]}\end{array}$ \\
\hline White Collar Management & $\begin{array}{c}0.097 \\
{[0.070]}\end{array}$ & $\begin{array}{c}-0.299^{* * *} * \\
{[0.108]}\end{array}$ \\
\hline Self-employment: & & \\
\hline Professional Services & $\begin{array}{l}-0.058 \\
{[0.052]}\end{array}$ & $\begin{array}{l}-0.017 \\
{[0.085]}\end{array}$ \\
\hline Other Self-employment & $\begin{array}{c}0.041 \\
{[0.043]}\end{array}$ & $\begin{array}{l}-0.046 \\
{[0.067]}\end{array}$ \\
\hline Agriculture & $\begin{array}{l}-0.228 \\
{[0.147]}\end{array}$ & $\begin{array}{c}0.317 \\
{[0.307]}\end{array}$ \\
\hline
\end{tabular}


Table A.1: continued: Determinants of Reciprocity

\begin{tabular}{|c|c|c|c|c|}
\hline Dependent Variable: & $\begin{array}{c}\text { Positive } \\
(1)\end{array}$ & $\begin{array}{c}\text { Reciprocity } \\
(2)\end{array}$ & $\begin{array}{c}\text { Negative } \\
(3)\end{array}$ & $\begin{array}{c}\text { Reciprocity } \\
(4)\end{array}$ \\
\hline \multicolumn{5}{|l|}{ Trainees/Apprentices } \\
\hline Apprentice (technical) & & $\begin{array}{l}-0.117 \\
{[0.072]}\end{array}$ & & $\begin{array}{c}-0.06 \\
{[0.108]}\end{array}$ \\
\hline Apprentice (clerical) & & $\begin{array}{c}-0.139^{*} \\
{[0.074]}\end{array}$ & & $\begin{array}{c}0.12 \\
{[0.125]}\end{array}$ \\
\hline Intern/Trainee & & $\begin{array}{l}-0.048 \\
{[0.126]}\end{array}$ & & $\begin{array}{c}0.133 \\
{[0.171]}\end{array}$ \\
\hline Retired (Pension) & & $\begin{array}{l}-0.066^{*} \\
{[0.034]}\end{array}$ & & $\begin{array}{c}0.113^{* *} \\
{[0.055]}\end{array}$ \\
\hline Non-Employed & & $\begin{array}{c}-0.078^{* * * *} \\
{[0.029]}\end{array}$ & & $\begin{array}{c}0.127^{* * *} * \\
{[0.047]}\end{array}$ \\
\hline School Degree & & $\begin{array}{c}0.007 \\
{[0.057]}\end{array}$ & & $\begin{array}{c}0.007 \\
{[0.095]}\end{array}$ \\
\hline Abitur & & $\begin{array}{l}0.042 * * \\
{[0.019]}\end{array}$ & & $\begin{array}{c}-0.204 * * * \\
{[0.029]}\end{array}$ \\
\hline Bad Subjective Health Status & & $\begin{array}{c}-0.051^{* * *} \\
{[0.009]}\end{array}$ & & $\begin{array}{c}0.077^{* * *} \\
{[0.014]}\end{array}$ \\
\hline \multicolumn{5}{|l|}{ Month of Interview: } \\
\hline February & & $\begin{array}{c}-0.474 * * * \\
{[0.130]}\end{array}$ & & $\begin{array}{l}-0.379 \\
{[0.496]}\end{array}$ \\
\hline March & & $\begin{array}{c}-0.497^{* * *} \\
{[0.130]}\end{array}$ & & $\begin{array}{c}-0.47 \\
{[0.496]}\end{array}$ \\
\hline April & & $\begin{array}{c}-0.510^{* * * *} \\
{[0.131]}\end{array}$ & & $\begin{array}{l}-0.443 \\
{[0.497]}\end{array}$ \\
\hline May & & $\begin{array}{c}-0.535^{* * *} \\
{[0.133]}\end{array}$ & & $\begin{array}{l}-0.479 \\
{[0.498]}\end{array}$ \\
\hline June & & $\begin{array}{c}-0.525 * * * \\
{[0.135]}\end{array}$ & & $\begin{array}{l}-0.542 \\
{[0.499]}\end{array}$ \\
\hline July & & $\begin{array}{c}-0.565^{* * *} \\
{[0.138]}\end{array}$ & & $\begin{array}{c}-0.48 \\
{[0.501]}\end{array}$ \\
\hline August & & $\begin{array}{c}-0.636^{* * *} \\
{[0.152]}\end{array}$ & & $\begin{array}{l}-0.596 \\
{[0.513]}\end{array}$ \\
\hline September & & $\begin{array}{c}-0.543^{* * *} \\
{[0.182]}\end{array}$ & & $\begin{array}{c}-0.72 \\
{[0.515]}\end{array}$ \\
\hline October & & $\begin{array}{l}-0.059 \\
{[0.217]}\end{array}$ & & $\begin{array}{l}-0.676 \\
{[0.596]}\end{array}$ \\
\hline Constant & $\begin{array}{c}5.138^{* * * *} \\
{[0.199]}\end{array}$ & $\begin{array}{c}5.998^{* * *} * \\
{[0.258]}\end{array}$ & $\begin{array}{c}3.967 * * * \\
{[0.311]}\end{array}$ & $\begin{array}{c}4.132^{* * * *} \\
{[0.608]}\end{array}$ \\
\hline Other Controls & No & Yes & No & Yes \\
\hline Observations & 19,821 & 16,826 & 19,769 & 16,784 \\
\hline R-squared & 0.003 & 0.01 & 0.03 & 0.06 \\
\hline
\end{tabular}

OLS coefficient estimates. The dependent variable in columns (1) and (2) is a measure for positive reciprocity, reflecting the average agreement to three statements concerning, respectively, willingness to return a favor, to go out of the way to help somebody who was kind, and undergo personal costs to help someone who was helpful before. The dependent variable in columns (3) and (4) is a measure for negative reciprocity, reflecting the avent variable in pero the average agrente serious wrong, to retaliate for being put in a diffcult postion, and respond to an insult with an insult. Answers are always on a scale from 1 to 7 , where 1 means "does not apply to me at all" and 7 means "applies to me perfectly". Reference occupation is qualified white collars in private sector. Robust standard errors in brackets allow for clustering
at the household level; ***,**,* indicate significance at $1-, 5-$, and 10 -percent level, respectively. 
Table A.2: Consequences of Reciprocity: Overall Life Satisfaction

\begin{tabular}{|c|c|c|c|}
\hline \multirow[t]{2}{*}{ Dependent Variable: } & \multicolumn{3}{|c|}{ Overall Life Satisfaction } \\
\hline & (1) & $(2)$ & $(3)$ \\
\hline Positive Reciprocity & $\begin{array}{c}0.163^{* * *} \\
{[0.015]}\end{array}$ & & $\begin{array}{c}0.166^{* * *} \\
{[0.015]}\end{array}$ \\
\hline Negative Reciprocity & & $\begin{array}{c}-0.094^{* * *} \\
{[0.009]}\end{array}$ & $\begin{array}{c}-0.100^{* * *} \\
{[0.009]}\end{array}$ \\
\hline Female & $\begin{array}{c}0.171^{* * *} \\
{[0.035]}\end{array}$ & $\begin{array}{c}0.149 * * * \\
{[0.035]}\end{array}$ & $\begin{array}{c}0.138^{* * *} * \\
{[0.035]}\end{array}$ \\
\hline Age (in years) & $\begin{array}{c}0.011^{* * *} \\
{[0.002]}\end{array}$ & $\begin{array}{c}0.010^{* * *} \\
{[0.002]}\end{array}$ & $\begin{array}{c}0.009^{* * * *} \\
{[0.002]}\end{array}$ \\
\hline Height (in cm) & $\begin{array}{c}0.007 * * * \\
{[0.002]}\end{array}$ & $\begin{array}{c}0.007 * * * \\
{[0.002]}\end{array}$ & $\begin{array}{c}0.007^{* * *} \\
{[0.002]}\end{array}$ \\
\hline Abitur Mother & $\begin{array}{c}0.054 \\
{[0.054]}\end{array}$ & $\begin{array}{c}0.052 \\
{[0.055]}\end{array}$ & $\begin{array}{c}0.049 \\
{[0.054]}\end{array}$ \\
\hline Abitur Father & $\begin{array}{l}0.069^{*} \\
{[0.042]}\end{array}$ & $\begin{array}{l}0.076^{*} \\
{[0.042]}\end{array}$ & $\begin{array}{l}0.070^{*} \\
{[0.042]}\end{array}$ \\
\hline Married & $\begin{array}{c}0.206^{* * *} \\
{[0.046]}\end{array}$ & $\begin{array}{c}0.211^{* * *} * \\
{[0.046]}\end{array}$ & $\begin{array}{c}0.204^{* * * *} \\
{[0.046]}\end{array}$ \\
\hline Divorced & $\begin{array}{c}-0.201 * * * \\
{[0.066]}\end{array}$ & $\begin{array}{c}-0.201^{* * *} \\
{[0.066]}\end{array}$ & $\begin{array}{c}-0.210^{* * *} * \\
{[0.066]}\end{array}$ \\
\hline Widowed & $\begin{array}{l}-0.027 \\
{[0.075]}\end{array}$ & $\begin{array}{l}-0.037 \\
{[0.075]}\end{array}$ & $\begin{array}{c}-0.04 \\
{[0.074]}\end{array}$ \\
\hline 1 Child born after 1987 & $\begin{array}{c}-0.083^{*} \\
{[0.044]}\end{array}$ & $\begin{array}{c}-0.091 * * \\
{[0.044]}\end{array}$ & $\begin{array}{c}-0.086^{* *} \\
{[0.044]}\end{array}$ \\
\hline 2 Children born after 1987 & $\begin{array}{c}-0.130 * * \\
{[0.051]}\end{array}$ & $\begin{array}{c}-0.150^{* * *} \\
{[0.051]}\end{array}$ & $\begin{array}{c}-0.136 * * * \\
{[0.051]}\end{array}$ \\
\hline 3 Children born after 1987 & $\begin{array}{l}-0.044 \\
{[0.077]}\end{array}$ & $\begin{array}{l}-0.062 \\
{[0.078]}\end{array}$ & $\begin{array}{l}-0.061 \\
{[0.077]}\end{array}$ \\
\hline$>3$ Children born after 1987 & $\begin{array}{l}-0.049 \\
{[0.161]}\end{array}$ & $\begin{array}{l}-0.119 \\
{[0.158]}\end{array}$ & $\begin{array}{c}-0.09 \\
{[0.159]}\end{array}$ \\
\hline Catholic & $\begin{array}{c}0.021 \\
{[0.033]}\end{array}$ & $\begin{array}{c}0.026 \\
{[0.033]}\end{array}$ & $\begin{array}{c}0.029 \\
{[0.033]}\end{array}$ \\
\hline Other Christian confession & $\begin{array}{c}0.02 \\
{[0.106]}\end{array}$ & $\begin{array}{l}-0.014 \\
{[0.105]}\end{array}$ & $\begin{array}{l}-0.018 \\
{[0.105]}\end{array}$ \\
\hline Not religious & $\begin{array}{c}-0.340 * * * \\
{[0.091]}\end{array}$ & $\begin{array}{c}-0.325^{* * *} \\
{[0.090]}\end{array}$ & $\begin{array}{c}-0.337 * * * \\
{[0.090]}\end{array}$ \\
\hline No confession & $\begin{array}{c}-0.065^{*} \\
{[0.037]}\end{array}$ & $\begin{array}{l}-0.044 \\
{[0.037]}\end{array}$ & $\begin{array}{l}-0.041 \\
{[0.037]}\end{array}$ \\
\hline Missing Religion & $\begin{array}{l}0.128^{*} \\
{[0.074]}\end{array}$ & $\begin{array}{c}0.152^{* *} \\
{[0.074]}\end{array}$ & $\begin{array}{c}0.159^{* *} \\
{[0.073]}\end{array}$ \\
\hline Lived in GDR in 1989 & $\begin{array}{c}-0.489 * * * \\
{[0.039]}\end{array}$ & $\begin{array}{c}-0.491 * * * \\
{[0.039]}\end{array}$ & $\begin{array}{c}-0.498^{* * *} \\
{[0.038]}\end{array}$ \\
\hline Lived abroad in 1989 & $\begin{array}{l}-0.033 \\
{[0.081]}\end{array}$ & $\begin{array}{c}-0.04 \\
{[0.080]}\end{array}$ & $\begin{array}{l}-0.059 \\
{[0.080]}\end{array}$ \\
\hline Residence in 1989 missing & $\begin{array}{c}-0.455^{* * *} \\
{[0.161]}\end{array}$ & $\begin{array}{c}-0.495^{* * *} \\
{[0.163]}\end{array}$ & $\begin{array}{c}-0.499^{* * *} \\
{[0.162]}\end{array}$ \\
\hline German Nationality & $\begin{array}{c}0.102 \\
{[0.065]}\end{array}$ & $\begin{array}{c}0.079 \\
{[0.065]}\end{array}$ & $\begin{array}{c}0.095 \\
{[0.065]}\end{array}$ \\
\hline Enrolled in School/College/University & $\begin{array}{l}0.149^{*} \\
{[0.083]}\end{array}$ & $\begin{array}{c}0.109 \\
{[0.083]}\end{array}$ & $\begin{array}{c}0.13 \\
{[0.083]}\end{array}$ \\
\hline
\end{tabular}


Table A.2: continued: Consequences of Reciprocity (Life Satisfaction)

\begin{tabular}{|c|c|c|c|}
\hline \multirow[t]{2}{*}{ Dependent Variable: } & \multicolumn{3}{|c|}{ Overall Life Satisfaction } \\
\hline & $(1)$ & $(2)$ & $(3)$ \\
\hline \multicolumn{4}{|l|}{ Public Sector: } \\
\hline Unskilled Blue Collar & $\begin{array}{c}-0.471 * \\
{[0.267]}\end{array}$ & $\begin{array}{l}-0.422 \\
{[0.272]}\end{array}$ & $\begin{array}{l}-0.446 \\
{[0.273]}\end{array}$ \\
\hline Skilled Blue Collar & $\begin{array}{l}-0.102 \\
{[0.167]}\end{array}$ & {$\left[\begin{array}{c}-0.09 \\
{[0.162]}\end{array}\right]$} & $\begin{array}{l}-0.088 \\
{[0.164]}\end{array}$ \\
\hline Blue Collar Craftsman & $\begin{array}{l}0.136 \\
{[0.138]}\end{array}$ & $\begin{array}{c}0.191 \\
{[0.138]}\end{array}$ & $\begin{array}{c}0.169 \\
{[0.138]}\end{array}$ \\
\hline Blue Collar Foreman & $\begin{array}{c}-0.17 \\
{[0.500]}\end{array}$ & $\begin{array}{l}-0.116 \\
{[0.563]}\end{array}$ & $\begin{array}{l}-0.105 \\
{[0.527]}\end{array}$ \\
\hline Blue Collar Master & $\begin{array}{c}0.28 \\
{[0.392]}\end{array}$ & $\begin{array}{c}0.258 \\
{[0.381]}\end{array}$ & $\begin{array}{c}0.296 \\
{[0.406]}\end{array}$ \\
\hline Unskilled White Collar & $\begin{array}{l}-0.305 \\
{[0.257]}\end{array}$ & $\begin{array}{l}-0.324 \\
{[0.259]}\end{array}$ & $\begin{array}{l}-0.316 \\
{[0.257]}\end{array}$ \\
\hline Skilled White Collar & $\begin{array}{l}-0.176 \\
{[0.132]}\end{array}$ & $\begin{array}{c}-0.21 \\
{[0.131]}\end{array}$ & $\begin{array}{l}-0.204 \\
{[0.131]}\end{array}$ \\
\hline White Collar Technician & $\begin{array}{c}0.017 \\
{[0.069]}\end{array}$ & $\begin{array}{l}-0.006 \\
{[0.069]}\end{array}$ & $\begin{array}{l}-0.004 \\
{[0.069]}\end{array}$ \\
\hline Highly-Skilled White Collar & $\begin{array}{l}0.214^{* *} \\
{[0.084]}\end{array}$ & $\begin{array}{l}0.200^{* *} \\
{[0.082]}\end{array}$ & $\begin{array}{l}0.199^{* *} \\
{[0.083]}\end{array}$ \\
\hline White Collar Management & $\begin{array}{c}0.128 \\
{[0.424]}\end{array}$ & $\begin{array}{c}0.127 \\
{[0.415]}\end{array}$ & $\begin{array}{c}0.135 \\
{[0.412]}\end{array}$ \\
\hline Civil Servant & $\begin{array}{l}-0.009 \\
0.393]\end{array}$ & $\begin{array}{l}-0.027 \\
{[0.416]}\end{array}$ & $\begin{array}{l}-0.022 \\
{[0.405]}\end{array}$ \\
\hline Civil Servant Intermediate & $\begin{array}{l}0.132 \\
0.109]\end{array}$ & $\begin{array}{c}0.111 \\
{[0.110]}\end{array}$ & $\begin{array}{c}0.121 \\
{[0.112]}\end{array}$ \\
\hline Civil Servant High & $\begin{array}{l}0.321^{* * *} \\
{[0.081]}\end{array}$ & $\begin{array}{c}0.307^{* * *} \\
{[0.080]}\end{array}$ & $\begin{array}{c}0.319^{* * *} \\
{[0.080]}\end{array}$ \\
\hline Civil Servant Executive & $\begin{array}{c}0.298^{* * *} * \\
{[0.089]}\end{array}$ & $\begin{array}{c}0.275^{* * *} \\
{[0.090]}\end{array}$ & $\begin{array}{c}0.289 * * * \\
{[0.089]}\end{array}$ \\
\hline \multicolumn{4}{|l|}{ Private Sector: } \\
\hline Unskilled Blue Collar & $\begin{array}{l}-0.358^{* * *} \\
{[0.111]}\end{array}$ & $\begin{array}{l}-0.333^{* * *} \\
{[0.110]}\end{array}$ & $\begin{array}{c}-0.339 * * * \\
{[0.111]}\end{array}$ \\
\hline Skilled Blue Collar & $\begin{array}{l}-0.246^{* * *} \\
{[0.074]}\end{array}$ & $\begin{array}{l}-0.224^{* * *} \\
{[0.074]}\end{array}$ & $\begin{array}{c}-0.224^{* * *} \\
{[0.074]}\end{array}$ \\
\hline Blue Collar Craftsman & $\begin{array}{l}-0.127^{*} \\
{[0.065]}\end{array}$ & $\begin{array}{l}-0.112^{*} \\
{[0.066]}\end{array}$ & $\begin{array}{c}-0.113^{*} \\
{[0.065]}\end{array}$ \\
\hline Blue Collar Foreman & $\begin{array}{c}0.048 \\
{[0.127]}\end{array}$ & $\begin{array}{c}0.119 \\
{[0.126]}\end{array}$ & $\begin{array}{c}0.088 \\
{[0.125]}\end{array}$ \\
\hline Blue Collar Master & $\begin{array}{l}-0.026 \\
{[0.133]}\end{array}$ & $\begin{array}{l}-0.042 \\
{[0.134]}\end{array}$ & $\begin{array}{l}-0.048 \\
{[0.134]}\end{array}$ \\
\hline Unskilled White Collar & $\begin{array}{c}-0.190^{*} \\
{[0.107]}\end{array}$ & $\begin{array}{c}-0.196^{*} \\
{[0.108]}\end{array}$ & $\begin{array}{c}-0.196^{*} \\
{[0.107]}\end{array}$ \\
\hline White Collar Technician & $\begin{array}{l}-0.099 \\
{[0.073]}\end{array}$ & $\begin{array}{l}-0.077 \\
{[0.073]}\end{array}$ & $\begin{array}{l}-0.086 \\
{[0.072]}\end{array}$ \\
\hline Highly-Skilled White Collar & $\begin{array}{l}0.115^{*} \\
{[0.059]}\end{array}$ & $\begin{array}{l}0.103^{*} \\
{[0.059]}\end{array}$ & $\begin{array}{l}0.112^{*} \\
{[0.059]}\end{array}$ \\
\hline White Collar Management & $\begin{array}{c}0.364^{* * *} \\
{[0.106]}\end{array}$ & $\begin{array}{c}0.354^{* * *} * \\
{[0.105]}\end{array}$ & $\begin{array}{c}0.338 * * * \\
{[0.105]}\end{array}$ \\
\hline \multicolumn{4}{|l|}{ Self-employment: } \\
\hline Professional Services & $\begin{array}{c}0.022 \\
{[0.097]}\end{array}$ & $\begin{array}{c}0.006 \\
{[0.097]}\end{array}$ & $\begin{array}{c}0.025 \\
{[0.097]}\end{array}$ \\
\hline Other Self-employment & $\begin{array}{l}-0.057 \\
{[0.073]}\end{array}$ & $\begin{array}{l}-0.052 \\
{[0.073]}\end{array}$ & $\begin{array}{l}-0.061 \\
{[0.073]}\end{array}$ \\
\hline Agriculture & $\begin{array}{c}0.053 \\
{[0.179]}\end{array}$ & $\begin{array}{c}0.047 \\
{[0.172]}\end{array}$ & $\begin{array}{c}0.074 \\
{[0.174]}\end{array}$ \\
\hline
\end{tabular}


Table A.2: continued: Consequences of Reciprocity (Life Satisfaction)

\begin{tabular}{|c|c|c|c|}
\hline Dependent Variable: & $(1)^{\text {Over: }}$ & $\begin{array}{l}1 \text { Life Satis } \\
(2)\end{array}$ & $\begin{array}{l}\text { ction } \\
\text { (3) }\end{array}$ \\
\hline \multicolumn{4}{|l|}{ Trainees/Apprentices } \\
\hline Apprentice (technical) & $\begin{array}{c}0.352^{* * *} \\
{[0.114]}\end{array}$ & $\begin{array}{c}0.328^{* * *} \\
{[0.114]}\end{array}$ & $\begin{array}{c}0.344^{* * *} \\
{[0.114]}\end{array}$ \\
\hline Apprentice (clerical) & $\begin{array}{l}0.267^{* *} \\
{[0.121]}\end{array}$ & $\begin{array}{c}0.249^{* *} \\
{[0.121]}\end{array}$ & $\begin{array}{l}0.273^{* *} \\
{[0.121]}\end{array}$ \\
\hline Intern/Trainee & $\begin{array}{c}0.222 \\
{[0.212]}\end{array}$ & $\begin{array}{c}0.228 \\
{[0.207]}\end{array}$ & $\begin{array}{c}0.232 \\
{[0.207]}\end{array}$ \\
\hline Unemployed & $\begin{array}{c}-1.149^{* * *} * \\
{[0.076]}\end{array}$ & $\begin{array}{c}-1.145^{* * *} * \\
{[0.076]}\end{array}$ & $\begin{array}{c}-1.129 * * * \\
0.076]\end{array}$ \\
\hline Non-Participating & $\begin{array}{c}0.033 \\
{[0.066]}\end{array}$ & $\begin{array}{c}0.036 \\
{[0.066]}\end{array}$ & $\begin{array}{c}0.03 \\
{[0.066]}\end{array}$ \\
\hline Retired (Pension) & $\begin{array}{l}0.107^{*} \\
{[0.059]}\end{array}$ & $\begin{array}{l}0.106^{*} \\
{[0.059]}\end{array}$ & $\begin{array}{l}0.122^{* *} \\
{[0.059]}\end{array}$ \\
\hline School Degree & $\begin{array}{c}0.13 \\
{[0.100]}\end{array}$ & $\begin{array}{c}0.124 \\
{[0.100]}\end{array}$ & $\begin{array}{c}0.129 \\
{[0.101]}\end{array}$ \\
\hline Abitur & $\begin{array}{c}0.123 * * * \\
{[0.033]}\end{array}$ & $\begin{array}{c}0.110^{* * *} \\
{[0.033]}\end{array}$ & $\begin{array}{c}0.102^{* * *} \\
{[0.033]}\end{array}$ \\
\hline Bad Subjective Health Status & $\begin{array}{c}-0.843^{* * *} \\
{[0.017]}\end{array}$ & $\begin{array}{c}-0.847^{* * *} * \\
{[0.017]}\end{array}$ & $\begin{array}{c}-0.835^{* * *} * \\
{[0.017]}\end{array}$ \\
\hline Log Monthly Income & $\begin{array}{c}0.018^{* * *} * \\
{[0.006]}\end{array}$ & $\begin{array}{c}0.019^{* * *} \\
{[0.006]}\end{array}$ & $\begin{array}{c}0.016^{* * *} \\
{[0.006]}\end{array}$ \\
\hline Month of Interview: & & & \\
\hline February & $\begin{array}{l}-0.011 \\
{[0.366]}\end{array}$ & $\begin{array}{l}-0.129 \\
{[0.376]}\end{array}$ & $\begin{array}{c}-0.05 \\
{[0.381]}\end{array}$ \\
\hline March & {$\left[\begin{array}{c}-0.1 \\
0.366]\end{array}\right.$} & $\begin{array}{l}-0.232 \\
{[0.376]}\end{array}$ & $\begin{array}{l}-0.148 \\
{[0.381]}\end{array}$ \\
\hline April & $\begin{array}{l}-0.084 \\
{[0.367]}\end{array}$ & $\begin{array}{l}-0.214 \\
{[0.377]}\end{array}$ & $\begin{array}{l}-0.129 \\
{[0.382]}\end{array}$ \\
\hline May & $\begin{array}{l}-0.064 \\
{[0.368]}\end{array}$ & $\begin{array}{l}-0.201 \\
{[0.378]}\end{array}$ & $\begin{array}{c}-0.11 \\
{[0.383]}\end{array}$ \\
\hline June & $\begin{array}{c}-0.14 \\
{[0.370]}\end{array}$ & $\begin{array}{l}-0.301 \\
{[0.379]}\end{array}$ & $\begin{array}{l}-0.217 \\
{[0.384]}\end{array}$ \\
\hline July & $\begin{array}{l}-0.176 \\
0.373]\end{array}$ & $\begin{array}{l}-0.322 \\
0.3821\end{array}$ & -0.227 \\
\hline August & $\begin{array}{c}0.077 \\
{[0.385]}\end{array}$ & $\begin{array}{l}-0.091 \\
{[0.394]}\end{array}$ & $\begin{array}{c}0.014 \\
0.399]\end{array}$ \\
\hline September & $\begin{array}{c}0.182 \\
{[0.396]}\end{array}$ & $\begin{array}{c}0.02 \\
{[0.404]}\end{array}$ & $\begin{array}{c}0.109 \\
{[0.410]}\end{array}$ \\
\hline October & $\begin{array}{c}0.335 \\
{[0.519]}\end{array}$ & $\begin{array}{c}0.252 \\
{[0.535]}\end{array}$ & $\begin{array}{c}0.262 \\
{[0.527]}\end{array}$ \\
\hline Constant & $\begin{array}{c}6.251^{* * *} \\
{[0.536]}\end{array}$ & $\begin{array}{c}7.605^{* * *} * \\
{[0.536]}\end{array}$ & $\begin{array}{c}6.651^{* * *} \\
{[0.546]}\end{array}$ \\
\hline Other Controls & Yes & Yes & Yes \\
\hline Observations & 16800 & 16757 & 16698 \\
\hline R-squared & 0.26 & 0.26 & 0.27 \\
\hline
\end{tabular}

OLS coefficient estimates. The dependent variable is the answer to a question on overall life satisfaction on a scale from 0 to 10, where 0 means "entirely dissatisfied with my life" and 10 means "absolutely satisfied". The misasure level of agreement to three statements concerning, romebody to take revenge for native reciprocity reflects average agreement to statements concerning willingness to take revenge for a serious wrong, to retaliate for being put in a difficult position, and to respond to an insult with an insult. Answers are always on a scale from 1 to 7 , where 1 means "does not apply to me at all" and 7 means "applies to me perfectly". Reference occupation is qualified white collars in private sector. Income is logged sum of income from all sources including non-labor income, social support, unemployment insurance and any other support (plus 1). Robust standard errors in brackets allow for clustering at the household level; ***, **, * indicate significance at $1-, 5-$, and 10 -percent level, respectively. 
Table A.3: Consequences of Reciprocity: Income

\begin{tabular}{|c|c|c|c|c|}
\hline \multirow{2}{*}{$\begin{array}{l}\text { Dependent Variable: } \\
\text { Positive Reciprocity }\end{array}$} & \multicolumn{4}{|c|}{$\begin{array}{c}\text { Log Gross Monthly Income } \\
(2)\end{array}$} \\
\hline & $\begin{array}{c}0.021^{* * *} \\
{[0.008]}\end{array}$ & & $\begin{array}{c}0.020^{* * *} \\
{[0.008]}\end{array}$ & $\begin{array}{c}0.005 \\
{[0.006]}\end{array}$ \\
\hline Negative Reciprocity & & $\begin{array}{c}0.006 \\
{[0.005]}\end{array}$ & $\begin{array}{c}{[0.0006} \\
0.006 \\
{[0.005]}\end{array}$ & $\begin{array}{c}0.004 \\
0.004]\end{array}$ \\
\hline Years of Education & $\begin{array}{c}0.015^{* * *} \\
{[0.004]}\end{array}$ & $\begin{array}{c}0.015^{* * *} \\
{[0.004]}\end{array}$ & $\begin{array}{c}0.015^{* * *} \\
{[0.004]}\end{array}$ & $\begin{array}{c}0.023^{* * *} * \\
{[0.003]}\end{array}$ \\
\hline Experience & $\begin{array}{c}0.047^{* * *} \\
{[0.003]}\end{array}$ & $\begin{array}{l}0.047^{* * *} \\
{[0.003]}\end{array}$ & $\begin{array}{c}0.047^{* * *} \\
{[0.003]}\end{array}$ & $\begin{array}{c}0.039^{* * *} \\
{[0.002]}\end{array}$ \\
\hline Experience $^{2}$ & $\begin{array}{c}-0.001 * * * \\
{[0.000]}\end{array}$ & $\begin{array}{c}-0.001 * * * \\
{[0.000]}\end{array}$ & $\begin{array}{c}-0.001 * * * \\
{[0.000]}\end{array}$ & $\begin{array}{c}-0.001 * * * \\
{[0.000]}\end{array}$ \\
\hline Female & $\begin{array}{c}-0.530 * * * \\
{[0.015]}\end{array}$ & $\begin{array}{c}-0.528^{* * *} \\
{[0.015]}\end{array}$ & $\begin{array}{c}-0.529^{* * *} \\
{[0.015]}\end{array}$ & $\begin{array}{c}-0.222 * * * \\
{[0.013]}\end{array}$ \\
\hline \multicolumn{5}{|l|}{ Public Sector: } \\
\hline Unskilled Blue Collar & $\begin{array}{c}-0.975^{* * *} \\
{[0.182]}\end{array}$ & $\begin{array}{c}-0.848^{* * *} \\
{[0.137]}\end{array}$ & $\begin{array}{c}-0.852^{* * *} \\
{[0.137]}\end{array}$ & $\begin{array}{c}-0.563^{* * *} \\
{[0.113]}\end{array}$ \\
\hline Skilled Blue Collar & $\begin{array}{c}-0.427 * * * \\
{[0.071]}\end{array}$ & $\begin{array}{c}-0.429 * * * \\
{[0.071]}\end{array}$ & $\begin{array}{c}-0.428^{* * *} \\
{[0.071]}\end{array}$ & $\begin{array}{c}-0.294^{* * *} \\
{[0.059]}\end{array}$ \\
\hline Blue Collar Craftsman & $\begin{array}{c}-0.164 * * * \\
{[0.039]}\end{array}$ & $\begin{array}{c}-0.164^{* * *} \\
{[0.039]}\end{array}$ & $\begin{array}{c}-0.167 * * * \\
{[0.039]}\end{array}$ & $\begin{array}{c}-0.155^{* * *} * \\
{[0.035]}\end{array}$ \\
\hline Blue Collar Foreman & $\begin{array}{l}-0.087 \\
{[0.064]}\end{array}$ & $\begin{array}{l}-0.087 \\
{[0.063]}\end{array}$ & $\begin{array}{l}-0.089 \\
{[0.063]}\end{array}$ & $\begin{array}{l}-0.045 \\
{[0.089]}\end{array}$ \\
\hline Blue Collar Master & $\begin{array}{c}0.019 \\
{[0.059]}\end{array}$ & $\begin{array}{c}0.014 \\
{[0.061]}\end{array}$ & $\begin{array}{c}0.018 \\
{[0.060]}\end{array}$ & $\begin{array}{l}-0.002 \\
{[0.061]}\end{array}$ \\
\hline Unskilled White Collar & $\begin{array}{c}-0.420 * * * \\
{[0.083]}\end{array}$ & $\begin{array}{c}-0.421^{* * *} \\
{[0.083]}\end{array}$ & $\begin{array}{c}-0.419^{* * *} \\
{[0.084]}\end{array}$ & $\begin{array}{c}-0.215^{* * *} \\
{[0.062]}\end{array}$ \\
\hline Skilled White Collar & $\begin{array}{c}-0.114^{* *} \\
{[0.048]}\end{array}$ & $\begin{array}{c}-0.110^{* *} \\
{[0.048]}\end{array}$ & $\begin{array}{c}-0.109^{* *} \\
{[0.048]}\end{array}$ & $\begin{array}{l}-0.041 \\
{[0.036]}\end{array}$ \\
\hline White Collar Technician & $\begin{array}{c}0.123^{* * *} \\
{[0.025]}\end{array}$ & $\begin{array}{c}0.124^{* * *} * \\
0.025]\end{array}$ & $\begin{array}{c}0.123^{* * *} * \\
{[0.025]}\end{array}$ & $\begin{array}{c}0.129^{* * *} * \\
{[0.018]}\end{array}$ \\
\hline Highly-Skilled White Collar & $\begin{array}{c}0.436^{* * *} \\
{[0.031]}\end{array}$ & $\begin{array}{c}0.441^{* * *} \\
{[0.031]}\end{array}$ & $\begin{array}{c}0.437^{* * *} \\
{[0.031]}\end{array}$ & $\begin{array}{c}0.255^{* * *} \\
{[0.027]}\end{array}$ \\
\hline White Collar Management & $\begin{array}{c}0.765^{* * *} \\
{[0.092]}\end{array}$ & $\begin{array}{c}0.765^{* * *} \\
{[0.090]}\end{array}$ & $\begin{array}{c}0.766^{* * *} \\
{[0.092]}\end{array}$ & $0.278^{* * *}$ \\
\hline Civil Servant & $-0.166^{* *}$ & $-0.165^{* *}$ & $-0.165^{* *}$ & $-0.180^{*}$ \\
\hline Civil Servant Intermediate & $\begin{array}{c}{\left[0.063^{* *}\right.} \\
0.032]\end{array}$ & $\begin{array}{l}{[0.001]} \\
0.058^{*} \\
{[0.032]}\end{array}$ & $\begin{array}{l}0.061^{*} \\
{[0.033]}\end{array}$ & $\begin{array}{l}{\left[0.046^{*}\right.} \\
0.028]\end{array}$ \\
\hline Civil Servant High & $\begin{array}{c}0.330 * * * \\
{[0.027]}\end{array}$ & $\begin{array}{c}0.329^{* * *} \\
{[0.027]}\end{array}$ & $\begin{array}{c}\left.0.330^{* * *}\right] \\
{[0.027]}\end{array}$ & $\begin{array}{c}{\left[0.0233^{* * *}\right.} \\
{[0.022]}\end{array}$ \\
\hline Civil Servant Executive & $\begin{array}{c}0.514^{* * *} \\
{[0.036]}\end{array}$ & $\begin{array}{c}0.516^{* * *} \\
{[0.036]}\end{array}$ & $\begin{array}{c}0.517^{* * *} \\
{[0.036]}\end{array}$ & $\begin{array}{c}0.373^{* * *} \\
{[0.032]}\end{array}$ \\
\hline \multicolumn{5}{|l|}{ Private Sector: } \\
\hline Unskilled Blue Collar & $\begin{array}{c}-1.078^{* * *} \\
{[0.054]}\end{array}$ & $\begin{array}{c}-1.079 * * * \\
{[0.054]}\end{array}$ & $\begin{array}{c}-1.078^{* * *} \\
{[0.054]}\end{array}$ & $\begin{array}{c}-0.702 * * * \\
{[0.042]}\end{array}$ \\
\hline Skilled Blue Collar & $\begin{array}{c}-0.452^{* * *} \\
{[0.031]}\end{array}$ & $\begin{array}{c}-0.455^{* * *} \\
{[0.031]}\end{array}$ & $\begin{array}{c}-0.453^{* * *} \\
{[0.031]}\end{array}$ & $\begin{array}{c}-0.334^{* * *} \\
{[0.023]}\end{array}$ \\
\hline Blue Collar Craftsman & $\begin{array}{c}-0.207 * * * \\
{[0.023]}\end{array}$ & $\begin{array}{c}-0.206 * * * \\
{[0.023]}\end{array}$ & $\begin{array}{c}-0.206 * * * \\
{[0.023]}\end{array}$ & $\begin{array}{c}-0.202^{* * *} \\
{[0.020]}\end{array}$ \\
\hline Blue Collar Foreman & $\begin{array}{l}-0.016 \\
{[0.034]}\end{array}$ & $\begin{array}{l}-0.011 \\
{[0.034]}\end{array}$ & $\begin{array}{l}-0.014 \\
{[0.034]}\end{array}$ & $-0.067^{*}$ \\
\hline Blue Collar Master & $\begin{array}{c}{[0.040} \\
0 \\
{[0.044]}\end{array}$ & $\begin{array}{l}-0.007 \\
{[0.044]}\end{array}$ & $\begin{array}{c}{\left[\begin{array}{c}0.004] \\
0 \\
{[0.044]}\end{array}\right]} \\
{\left[\begin{array}{l}0 \\
0\end{array}\right]}\end{array}$ & $\begin{array}{c}-0.083^{*} \\
{[0.044]}\end{array}$ \\
\hline Unskilled White Collar & $\begin{array}{c}-0.868^{* * *} \\
{[0.050]}\end{array}$ & $\begin{array}{c}-0.863^{* * *} \\
{[0.050]}\end{array}$ & $\begin{array}{c}-0.869^{* * *} \\
{[0.050]}\end{array}$ & $\begin{array}{c}-0.563 * * * \\
{[0.035]}\end{array}$ \\
\hline White Collar Technician & $\begin{array}{c}-0.378^{* * *} * \\
{[0.033]}\end{array}$ & $\begin{array}{c}-0.377^{* * * *} \\
{[0.033]}\end{array}$ & $\begin{array}{c}-0.377^{* * *} * \\
{[0.033]}\end{array}$ & $\begin{array}{c}-0.269 * * * \\
{[0.024]}\end{array}$ \\
\hline Highly-Skilled White Collar & $\begin{array}{c}0.463^{* * *} \\
{[0.026]}\end{array}$ & $\begin{array}{c}0.464^{* * *} \\
{[0.026]}\end{array}$ & $\begin{array}{c}0.464 * * * \\
{[0.026]}\end{array}$ & $\begin{array}{c}0.296^{* * *} * \\
{[0.021]}\end{array}$ \\
\hline White Collar Management & $\begin{array}{c}0.755^{* * *} \\
{[0.050]}\end{array}$ & $\begin{array}{c}0.759^{* * *} \\
{[0.050]}\end{array}$ & $\begin{array}{c}0.756^{* * *} * \\
{[0.050]}\end{array}$ & $\begin{array}{c}0.373^{* * *} \\
{[0.049]}\end{array}$ \\
\hline \multicolumn{5}{|l|}{ Self-employment: } \\
\hline Professional Services & $\begin{array}{c}0.319^{* * *} \\
{[0.067]}\end{array}$ & $\begin{array}{c}0.318^{* * *} \\
{[0.066]}\end{array}$ & $\begin{array}{c}0.320^{* * *} \\
{[0.067]}\end{array}$ & $\begin{array}{c}0.180^{* * *} * \\
{[0.056]}\end{array}$ \\
\hline Other Self-employment & $\begin{array}{l}-0.067 \\
{[0.045]}\end{array}$ & $\begin{array}{l}-0.068 \\
{[0.045]}\end{array}$ & $\begin{array}{l}-0.069 \\
{[0.045]}\end{array}$ & $\begin{array}{c}-0.277^{*} * * \\
{[0.041]}\end{array}$ \\
\hline Agriculture & $\begin{array}{c}-0.464^{* * *} \\
{[0.130]}\end{array}$ & $\begin{array}{c}-0.467^{* * *} \\
{[0.131]}\end{array}$ & $\begin{array}{c}-0.467^{* * *} \\
{[0.131]}\end{array}$ & $\begin{array}{c}-1.197 * * * \\
{[0.115]}\end{array}$ \\
\hline \multicolumn{5}{|l|}{ Trainees/Apprentices } \\
\hline Apprentice (technical) & $\begin{array}{c}-1.109 * * * \\
{[0.048]}\end{array}$ & $\begin{array}{c}-1.114^{* * *} \\
{[0.048]}\end{array}$ & $\begin{array}{c}-1.112^{* * *} \\
{[0.048]}\end{array}$ & $\begin{array}{c}-1.139 * * * \\
{[0.044]}\end{array}$ \\
\hline Apprentice (clerical) & $\begin{array}{c}-0.865^{* * *} \\
{[0.044]}\end{array}$ & $\begin{array}{c}-0.870^{* * *} \\
{[0.044]}\end{array}$ & $\begin{array}{c}-0.867^{* * *} \\
{[0.044]}\end{array}$ & $\begin{array}{c}-0.974^{* * * *} \\
{[0.038]}\end{array}$ \\
\hline Intern/Trainee & $\begin{array}{c}-1.077^{* * *} \\
{[0.117]}\end{array}$ & $\begin{array}{c}-1.079^{* * *} \\
{[0.117]}\end{array}$ & $\begin{array}{c}-1.078^{* * *} \\
{[0.117]}\end{array}$ & $\begin{array}{c}-1.001 * * * \\
{[0.106]}\end{array}$ \\
\hline Actual Weekly Hours & & & & \\
\hline Constant & $\begin{array}{c}7.058^{* * *} \\
{[0.074]}\end{array}$ & $\begin{array}{c}7.157 * * * \\
{[0.063]}\end{array}$ & $\begin{array}{c}7.040^{* * *} \\
{[0.077]}\end{array}$ & $\begin{array}{c}5.692^{* * * *} \\
{[0.068]}\end{array}$ \\
\hline Observations & 9893 & 9880 & 9856 & 9662 \\
\hline $\mathrm{R}$-squared & 0.48 & 0.49 & 0.49 & 0.66 \\
\hline
\end{tabular}

OLS coefficient estimates. The dependent variable is the answer to a question on gross labor income in the previous month, excluding bonuses and extra payments, but including remuneration for overtime. The measure of positive reciprocity is the individual's average level of agreement to three statements concerning, respectively, willingness to return a favor, to go out of the way to help somebody who was kind, and undergo personal costs to help someone who was helpful before. The measure of negative reciprocity reflects average agreement to statements concerning willingness to take revenge for a serious wrong, to retaliate for being put in a difficult position, and to respond to an insult with an insult. Answers are always on a scale from 1 to 7 , where 1 meass "does an apply to to all" an 7 mean "aplies to me per fectly". Robus stan ( Robust standard 10 -percent level, respectively. 
Table A.4: Consequences of Reciprocity: Hours Worked and Sickleave

\begin{tabular}{|c|c|c|c|c|c|}
\hline \multirow{2}{*}{ Dependent Variable: } & \multirow{2}{*}{$\begin{array}{c}\text { Actual Weekly } \\
\text { Hours Worked } \\
(1)\end{array}$} & \multirow{2}{*}{$\begin{array}{c}\text { Worked Overtime } \\
\text { last Month } \\
(2)\end{array}$} & \multirow{2}{*}{$\begin{array}{c}\text { Hours Overtime } \\
\text { last Month } \\
(3)\end{array}$} & \multicolumn{2}{|c|}{ Days of Sickleave } \\
\hline & & & & in 2003 & $\begin{array}{c}\text { in } 2004 \\
(5)\end{array}$ \\
\hline Positive Reciprocity & $0.222^{* *}$ & $0.021 * * *$ & $0.213^{* * *}$ & -0.173 & -0.058 \\
\hline & & {$[0.007]$} & & {$[0.386]$} & {$[0.456]$} \\
\hline Negative Reciprocity & -0.032 & $-0.012^{* * *}$ & -0.023 & $0.432^{*}$ & $0.514^{*}$ \\
\hline Bad Subjective Health Status & {$[0.068]$} & {$[0.004]$} & {$[0.046]$} & $\begin{array}{c}{[0.240]} \\
5.693^{* * *}\end{array}$ & $\begin{array}{c}{[0.283]} \\
7.586 * * *\end{array}$ \\
\hline Log Gross Monthly Income & $\begin{array}{c}10.297^{* * *} \\
{[0.190]}\end{array}$ & $\begin{array}{c}0.184^{* * *} \\
{[0.010]}\end{array}$ & $\begin{array}{c}0.981^{* * *} \\
{[0.136]}\end{array}$ & $\begin{array}{c}{\left[.472^{* * *}\right.} \\
{[0.601]}\end{array}$ & $\begin{array}{c}9.963^{* * *} \\
{[0.762]}\end{array}$ \\
\hline Years of Education & $\begin{array}{l}-0.429^{* * *} \\
{[0.049]}\end{array}$ & $\begin{array}{l}-0.002 \\
{[0.003]}\end{array}$ & $\begin{array}{l}-0.036 \\
{[0.030]}\end{array}$ & $\begin{array}{l}-0.563^{* * *} \\
{[0.168]}\end{array}$ & $\begin{array}{l}-0.675^{* * *} \\
{[0.199]}\end{array}$ \\
\hline Experience & $\begin{array}{c}-0.212^{* * *} * \\
{[0.038]}\end{array}$ & {$\left[\begin{array}{c}0 \\
{[0.002]}\end{array}\right]$} & $\begin{array}{c}0.007 \\
{[0.023]}\end{array}$ & $\begin{array}{l}-0.102 \\
{[0.134]}\end{array}$ & $\begin{array}{l}-0.013 \\
{[0.159]}\end{array}$ \\
\hline Experience $^{2}$ & $\begin{array}{l}0.001^{* *} \\
{[0.001]}\end{array}$ & $\begin{array}{c}-0.000^{* *} \\
{[0.000]}\end{array}$ & {$\left[\begin{array}{c}0 \\
0.000]\end{array}\right]$} & $\begin{array}{l}-0.002 \\
0.003]\end{array}$ & $\begin{array}{l}-0.006^{*} \\
{[0.003]}\end{array}$ \\
\hline Female & $\begin{array}{l}-3.843^{* * *} \\
{[0.232]}\end{array}$ & $\begin{array}{c}-0.022^{*} \\
{[0.013]}\end{array}$ & $\begin{array}{l}-0.778^{* * *} \\
{[0.137]}\end{array}$ & $\begin{array}{l}3.110^{* * *} \\
{[0.811]}\end{array}$ & $\begin{array}{l}5.571^{* * *} \\
{[0.956]}\end{array}$ \\
\hline Public Sector: & & & & & \\
\hline Unskilled Blue Collar & $\begin{array}{c}0.059 \\
{[1.557]}\end{array}$ & $\begin{array}{c}-0.198^{* * *} \\
{[0.075]}\end{array}$ & $\begin{array}{l}1.208 \\
{[1.927]}\end{array}$ & $\begin{array}{c}1.239 \\
{[5.059]}\end{array}$ & $\begin{array}{c}3.21 \\
{[5.966]}\end{array}$ \\
\hline Skilled Blue Collar & $\begin{array}{l}-0.153 \\
{[0.842]}\end{array}$ & $\begin{array}{c}-0.144^{* * *} \\
{[0.049]}\end{array}$ & $\begin{array}{l}-0.184 \\
{[0.748]}\end{array}$ & $\begin{array}{c}10.841^{* * *} \\
{[3.204]}\end{array}$ & $\begin{array}{c}16.861^{* * * *} \\
{[3.723]}\end{array}$ \\
\hline Blue Collar Craftsman & $\begin{array}{l}1.289^{* *} \\
{[0.583]}\end{array}$ & $\begin{array}{l}-0.074 \\
{[0.046]}\end{array}$ & $\begin{array}{l}-0.268 \\
{[0.364]}\end{array}$ & $\begin{array}{c}7.646^{* * *} \\
{[2.910]}\end{array}$ & $\begin{array}{l}8.710^{* * *} \\
{[3.367]}\end{array}$ \\
\hline Blue Collar Foreman & $\begin{array}{l}-0.619 \\
{[1.692]}\end{array}$ & $\begin{array}{l}-0.102 \\
{[0.139]}\end{array}$ & $\begin{array}{l}-0.632 \\
{[1.505]}\end{array}$ & $\begin{array}{l}17.717^{* *} \\
{[8.461]}\end{array}$ & $\begin{array}{l}20.690^{* *} \\
{[9.701]}\end{array}$ \\
\hline Blue Collar Master & $\begin{array}{c}0.381 \\
{[1.536]}\end{array}$ & $\begin{array}{l}-0.093 \\
{[0.113]}\end{array}$ & $\begin{array}{c}0.402 \\
{[1.400]}\end{array}$ & $\begin{array}{l}3.495 \\
{[7.368]}\end{array}$ & $\begin{array}{l}7.852 \\
{[8.518]}\end{array}$ \\
\hline Unskilled White Collar & $\begin{array}{l}-2.061^{*} \\
{[1.160]}\end{array}$ & $\left.\begin{array}{c}-0.09 \\
{[0.063]}\end{array}\right]$ & $\begin{array}{c}0.318 \\
{[0.386]}\end{array}$ & $\begin{array}{c}2.08 \\
{[3.782]}\end{array}$ & $\begin{array}{c}7.248 \\
{[4.442]}\end{array}$ \\
\hline Skilled White Collar & $\begin{array}{l}-1.136^{*} \\
{[0.636]}\end{array}$ & $\begin{array}{l}-0.049 \\
-0.040]\end{array}$ & $\begin{array}{l}0.088 \\
{[0.407]}\end{array}$ & $\begin{array}{l}4.907^{* *} \\
{[2.488]}\end{array}$ & $\begin{array}{c}9.675^{* * *} * \\
{[2.855]}\end{array}$ \\
\hline White Collar Technician & $\begin{array}{c}-1.568^{* * *} \\
{[0.333]}\end{array}$ & $\begin{array}{c}0.03 \\
{[0.024]}\end{array}$ & $\begin{array}{c}-0.512^{* * *} \\
{[0.186]}\end{array}$ & $\begin{array}{l}3.292^{* *} \\
{[1.421]}\end{array}$ & $\begin{array}{c}6.504^{* * *} \\
{[1.653]}\end{array}$ \\
\hline Highly-Skilled White Collar & $\begin{array}{c}0.975 \\
{[0.596]}\end{array}$ & $\begin{array}{c}0.024 \\
0.024 \\
{[0.032]}\end{array}$ & $\begin{array}{c}0.367 \\
{[0.316]}\end{array}$ & $\begin{array}{c}2.336 \\
{[1.941]}\end{array}$ & $\begin{array}{c}2.538 \\
{[2.269]}\end{array}$ \\
\hline White Collar Management & $\begin{array}{l}7.821^{* * *} \\
{[2.610]}\end{array}$ & $\begin{array}{c}0.151 \\
0.127]\end{array}$ & $\begin{array}{l}3.457^{* *} \\
{[1.711]}\end{array}$ & $\begin{array}{c}0.602 \\
0.564]\end{array}$ & $\begin{array}{r}-11.655 \\
{[9.714]}\end{array}$ \\
\hline Civil Servant & $\begin{array}{c}2.129 \\
{[1.692]}\end{array}$ & $\begin{array}{c}-0.225^{* *} \\
{[0.090]}\end{array}$ & $\begin{array}{c}0.759 \\
{[1.397]}\end{array}$ & $\begin{array}{l}11.447^{*} \\
{[6.872]}\end{array}$ & $\begin{array}{c}16.312^{* *} \\
{[7.399]}\end{array}$ \\
\hline Civil Servant Intermediate & $\begin{array}{l}-0.231 \\
{[0.561]}\end{array}$ & $\begin{array}{c}-0.092^{* *} \\
{[0.038]}\end{array}$ & $\begin{array}{l}-0.374 \\
{[0.424]}\end{array}$ & $\begin{array}{l}4.381^{*} \\
{[2.408]}\end{array}$ & $\begin{array}{c}8.065^{* * *} \\
{[2.746]}\end{array}$ \\
\hline Civil Servant High & $\begin{array}{l}-0.464 \\
{[0.504]}\end{array}$ & $\begin{array}{c}-0.078^{* *} \\
{[0.031]}\end{array}$ & $\begin{array}{c}-0.740^{* * *} * \\
{[0.235]}\end{array}$ & $\begin{array}{l}4.571^{* *} \\
{[1.920]}\end{array}$ & $\begin{array}{l}7.503^{* * *} \\
{[2.204]}\end{array}$ \\
\hline Civil Servant Executive & $\begin{array}{l}-0.992 \\
{[0.685]}\end{array}$ & $\begin{array}{c}-0.129^{* * *} * \\
{[0.036]}\end{array}$ & $\begin{array}{l}-0.056 \\
{[0.435]}\end{array}$ & $\begin{array}{l}1.305 \\
{[2.326]}\end{array}$ & $\begin{array}{l}1.469 \\
{[2.724]}\end{array}$ \\
\hline Private Sector: & & & & & \\
\hline Unskilled Blue Collar & $\begin{array}{l}-0.418 \\
{[0.634]}\end{array}$ & $\begin{array}{l}-0.154^{* * *} \\
{[0.033]}\end{array}$ & $\begin{array}{l}0.969^{*} \\
{[0.502]}\end{array}$ & $\begin{array}{c}1.621 \\
{[2.330]}\end{array}$ & $\begin{array}{l}-1.115 \\
{[2.819]}\end{array}$ \\
\hline Skilled Blue Collar & $\begin{array}{c}1.199^{* * *} \\
{[0.381]}\end{array}$ & $\begin{array}{c}-0.134^{* * *} \\
{[0.023]}\end{array}$ & $\begin{array}{l}0.645^{* *} \\
{[0.289]}\end{array}$ & $\begin{array}{c}4.863^{* * *} \\
{[1.503]}\end{array}$ & $\begin{array}{c}6.363^{* * *} \\
{[1.760]}\end{array}$ \\
\hline Blue Collar Craftsman & $\begin{array}{l}1.972^{* * *} \\
{[0.361]}\end{array}$ & $\begin{array}{c}-0.067^{* * *} * \\
{[0.022]}\end{array}$ & $\begin{array}{c}0.272 \\
{[0.218]}\end{array}$ & $\begin{array}{l}3.032^{* *} \\
{[1.355]}\end{array}$ & $\begin{array}{l}2.215 \\
{[1.614]}\end{array}$ \\
\hline Blue Collar Foreman & $\begin{array}{l}1.544^{* *} \\
{[0.695]}\end{array}$ & $\begin{array}{l}-0.017 \\
{[0.043]}\end{array}$ & $\begin{array}{l}-0.269 \\
{[0.395]}\end{array}$ & $\begin{array}{c}2.526 \\
{[2.712]}\end{array}$ & $\begin{array}{c}2.15 \\
{[3.173]}\end{array}$ \\
\hline Blue Collar Master & $\begin{array}{c}2.643^{* * *} \\
{[0.787]}\end{array}$ & $\begin{array}{l}-0.016 \\
{[0.047]}\end{array}$ & $\begin{array}{c}1.489^{* * * *} \\
{[0.540]}\end{array}$ & $\begin{array}{l}-2.456 \\
{[3.029]}\end{array}$ & $\begin{array}{l}-4.582 \\
{[3.750]}\end{array}$ \\
\hline Unskilled White Collar & $\begin{array}{l}-0.334 \\
{[0.619]}\end{array}$ & $\begin{array}{c}-0.126^{* * *} \\
{[0.033]}\end{array}$ & $\begin{array}{c}0.441 \\
{[0.392]}\end{array}$ & $\begin{array}{l}-0.377 \\
{[2.301]}\end{array}$ & $\begin{array}{l}-0.303 \\
{[2.724]}\end{array}$ \\
\hline White Collar Technician & $\begin{array}{c}0.67 \\
{[0.447]}\end{array}$ & $\begin{array}{l}-0.026 \\
{[0.026]}\end{array}$ & $\begin{array}{l}0.563^{*} \\
{[0.290]}\end{array}$ & $\begin{array}{l}-0.484 \\
{[1.639]}\end{array}$ & $\begin{array}{c}0.855 \\
{[1.953]}\end{array}$ \\
\hline Highly-Skilled White Collar & $\begin{array}{c}{[0.403} \\
0.403 \\
{[0.375]}\end{array}$ & $\begin{array}{l}{[0.020]} \\
0.045^{*} \\
{[0.024]}\end{array}$ & $\begin{array}{c}1.335^{* * *} * \\
{[0.236]}\end{array}$ & $\begin{array}{l}-1.908 \\
{[1.434]}\end{array}$ & $\begin{array}{c}-3.407^{* *} \\
{[1.699]}\end{array}$ \\
\hline White Collar Management & $\begin{array}{c}3.802^{* * *} \\
{[0.878]}\end{array}$ & $\begin{array}{l}-0.053 \\
{[0.045]}\end{array}$ & $\begin{array}{c}3.486^{* * *} \\
{[0.593]}\end{array}$ & $\begin{array}{c}-10.662^{* * *} \\
{[2.812]}\end{array}$ & $\begin{array}{c}-14.953^{* * * *} \\
{[3.431]}\end{array}$ \\
\hline Self-employment: & & & & & \\
\hline Professional Services & $\begin{array}{c}0.755 \\
{[0.861]}\end{array}$ & & $\begin{array}{c}0 \\
{[0.000]}\end{array}$ & $\begin{array}{c}-13.167 * * * \\
{[2.380]}\end{array}$ & $\begin{array}{c}-20.902^{* * *} \\
{[3.178]}\end{array}$ \\
\hline Other Self-employment & $\begin{array}{c}7.248^{* * *} \\
{[0.697]}\end{array}$ & & $\begin{array}{c}0 \\
{[0.000]}\end{array}$ & $\begin{array}{c}-11.288^{* * * *} \\
{[1.776]}\end{array}$ & $\begin{array}{c}-15.080^{* * * *} \\
{[2.250]}\end{array}$ \\
\hline Agriculture & $\begin{array}{c}28.075^{* * *} \\
{[2.508]}\end{array}$ & & $\begin{array}{c}0 \\
{[0.000]}\end{array}$ & $\begin{array}{c}0.663 \\
{[6.484]}\end{array}$ & $\begin{array}{l}-2.343 \\
{[8.023]}\end{array}$ \\
\hline Trainees/Apprentices & & & & & \\
\hline Apprentice (technical) & $\begin{array}{c}12.298^{* * *} \\
{[0.694]}\end{array}$ & $\begin{array}{l}-0.047 \\
{[0.043]}\end{array}$ & $\begin{array}{c}0.524 \\
{[0.510]}\end{array}$ & $\begin{array}{c}1.84 \\
{[2.999]}\end{array}$ & $\begin{array}{l}5.856^{*} \\
{[3.344]}\end{array}$ \\
\hline Apprentice (clerical) & $12.345^{* * *}$ & 0.008 & $\begin{array}{c}0.068 \\
{[0.443]}\end{array}$ & $\begin{array}{l}2.98 \\
{[3.300]}\end{array}$ & $8.691 * *$ \\
\hline Intern/Trainee & $\begin{array}{l}{[0.630]} \\
9.073^{* * *}\end{array}$ & $-0.132^{*}$ & $2.587^{* * *}$ & $-16.137^{* *}$ & -14.128 \\
\hline Constant & $\begin{array}{c}{[1.811]} \\
-30.584^{* * *}\end{array}$ & {$[0.080]$} & $\begin{array}{c}{[1.097]} \\
-4.188^{* * *}\end{array}$ & $\begin{array}{c}{[7.760]} \\
-44.619^{* * *}\end{array}$ & $\begin{array}{c}{[8.943]} \\
-103.135^{* * *}\end{array}$ \\
\hline & {$[1.773]$} & & {$[1.275]$} & {$[5.751]$} & {$[7.112]$} \\
\hline Observations & 9,662 & 8,941 & 4,314 & 8,345 & 8,896 \\
\hline R-squared & 0.53 & & 0.11 & & \\
\hline
\end{tabular}

The dependent variable in column (1) is the answer to questions on regular average weekly working time including overtime, entries are OLS coefficient estimates. The dependent variable in column (2) is a binary variable, taking the value 1 if an individual reports to have worked overtime in the past month, entries are binary Probit marginal effects. The dependent variable in column (3) is the answer to the question how many hours overtime an indivist (4) and (5) is the total the lat zero, estimates are Tobit coefients. The control for gross labor income refers to income in the previous month, excluding bonuses and extra payments, but including remuneration for overtime. The measure of positive reciprocity is the individual's average level of agreement to three statements concerning, respectively, willingness to return a favor, to go out of the way to help somebody who was kind, and undergo personal costs to help someone who was helpful before. The measure of negative reciprocity reflects average agreement to statements concerning willingness to take revenge for a serious wrong, to retaliate for being put in a difficult position, and to respond to an insult with an insult. Answers are always on a scale from 1 to 7 , where 1 mean "does not apply to me at all" and 7 means "applies to me perfectly". Robust standard errors in brackets allow for clustering at the household level; 